\title{
California State Waters Map Series-Offshore of Bodega Head, California
}

By Samuel Y. Johnson, Peter Dartnell, Nadine E. Golden, Stephen R. Hartwell, Mercedes D. Erdey, H. Gary Greene, Guy R. Cochrane, Rikk G. Kvitek, Michael W. Manson, Charles A. Endris, Bryan E. Dieter, Janet T. Watt, Lisa M. Krigsman, Ray W. Sliter, Erik N. Lowe, and John L. Chin

(Samuel Y. Johnson and Susan A. Cochran, editors)

Pamphlet to accompany

Open-File Report 2015-1140

2015

U.S. Department of the Interior

U.S. Geological Survey 


\section{U.S. Department of the Interior \\ SALLY JEWELL, Secretary}

\section{U.S. Geological Survey \\ Suzette M. Kimball, Acting Director}

U.S. Geological Survey, Reston, Virginia: 2015

For more information on the USGS—-the Federal source for science about the Earth, its natural and living resources, natural hazards, and the environment-visit

http://www.usgs.gov or call 1-888-ASK-USGS

For an overview of USGS information products, including maps, imagery, and publications, visit http://www.usgs.gov/pubprod

To order this and other USGS information products, visit http://store.usgs.gov

Any use of trade, product, or firm names is for descriptive purposes only and does not imply endorsement by the U.S. Government.

Although this report is in the public domain, permission must be secured from the individual copyright owners to reproduce any copyrighted material contained within this report.

Suggested citation:

Johnson, S.Y., Dartnell, P., Golden, N.E., Hartwell, S.R., Erdey, M.D., Greene, H.G., Cochrane, G.R., Kvitek, R.G., Manson, M.W., Endris, C.A., Dieter, B.E., Watt, J.T., Krigsman, L.M., Sliter, R.W., Lowe, E.N., and Chin, J.L. (S.Y. Johnson and S.A. Cochran, eds.), 2015, California State Waters Map Series-Offshore of Bodega Head, California: U.S. Geological Survey Open-File Report 2015-1140, pamphlet 39 p., 10 sheets, scale 1:24,000, http://dx.doi.org/10.3133/ofr20151140.

ISSN 2331-1258 (online) 


\section{Contents}

Preface

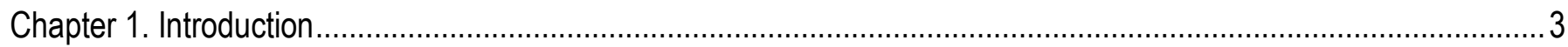

By Samuel Y. Johnson

Regional Setting 3

Publication Summary

Chapter 2. Bathymetry and Backscatter-Intensity Maps of the Offshore of Bodega Head Map Area (Sheets 1, 2, and 3).

By Peter Dartnell and Rikk G. Kvitek

Chapter 3. Data Integration and Visualization for the Offshore of Bodega Head Map Area (Sheet 4) 10

By Peter Dartnell

Chapter 4. Seafloor-Character Map of the Offshore of Bodega Head Map Area (Sheet 5)

By Mercedes D. Erdey and Guy R. Cochrane

Chapter 5. Ground-Truth Studies for the Offshore of Bodega Head Map Area (Sheet 6) 16

By Nadine E. Golden and Guy R. Cochrane

Chapter 6. Potential Marine Benthic Habitats of the Offshore of Bodega Head Map Area (Sheet 7) 19

By H. Gary Greene, Charles A. Endris, and Bryan E. Dieter

Classifying Potential Marine Benthic Habitats 19

Examples of Attribute Coding 21

Map Area Habitats...

Chapter 7. Subsurface Geology and Structure of the Offshore of Bodega Head Map Area and the Salt Point to Drakes Bay Region (Sheets 8 and 9).

By Samuel Y. Johnson, Stephen R. Hartwell, and Janet T. Watt

Data Acquisition. 22

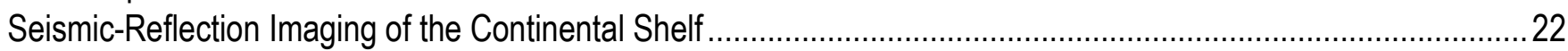

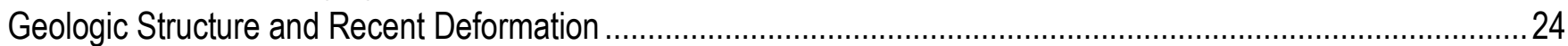

Thickness and Depth to Base of Uppermost Pleistocene and Holocene Deposits ...............................................2

Chapter 8. Geologic and Geomorphic Map of the Offshore of Bodega Head Map Area (Sheet 10)............................28

By Samuel Y. Johnson, Michael W. Manson, and Stephen R. Hartwell

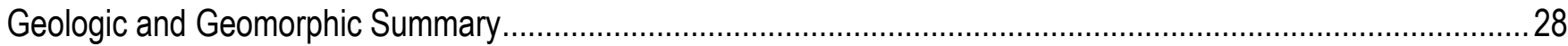

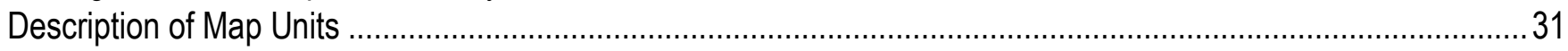

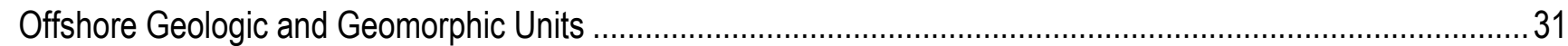

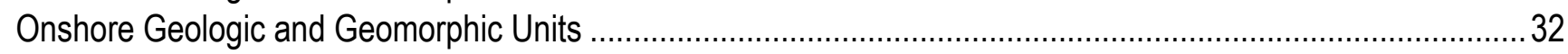

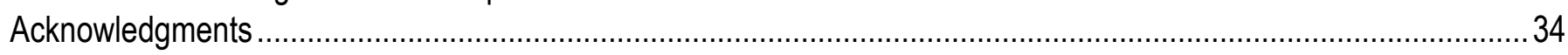

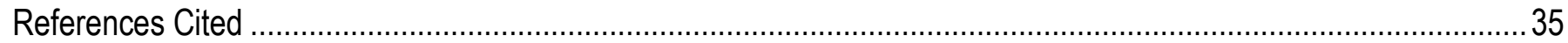

\section{Figures}

Figure 1-1. Physiography of northern California coast from Point Arena to San Francisco.......................................... 6

Figure 1-2. Coastal geography of Offshore of Bodega Head map area................................................................

Figure 4-1. Detailed view of ground-truth data, showing accuracy-assessment methodology.................................. 13

Figure 5-1. Photograph of camera sled used in USGS 2008 ground-truth survey. ............................................. 16

Figure 5-2. Graph showing distribution of primary and secondary substrate determined from video observations in Offshore of Bodega Head map area. 


\section{Tables}

Table 4-1. Conversion table showing how video observations of primary substrate, secondary substrate, and abiotic seafloor complexity are grouped into seafloor-character-map Classes I, II, III, and IV for use in supervised classification and accuracy assessment in Offshore Bodega Head map area.

Table 4-2. Accuracy-assessment statistics for seafloor-character-map classifications in Offshore of Bodega Head map area.

Table 7-1. Area, sediment-thickness, and sediment-volume data for California's State Waters in Salt Point to Drakes Bay region, as well as in Offshore of Bodega Head map area.

Table 8-1. Areas and relative proportions of offshore geologic map units in Offshore of Bodega Head map area.... 30

\section{Map Sheets}

Sheet 1. Colored Shaded-Relief Bathymetry, Offshore of Bodega Head Map Area, California By Peter Dartnell and Rikk G. Kvitek

Sheet 2. Shaded-Relief Bathymetry, Offshore of Bodega Head Map Area, California

By Peter Dartnell and Rikk G. Kvitek

Sheet 3. Acoustic Backscatter, Offshore of Bodega Head Map Area, California

By Peter Dartnell, Mercedes D. Erdey, and Rikk G. Kvitek

Sheet 4. Data Integration and Visualization, Offshore of Bodega Head Map Area, California

By Peter Dartnell

Sheet 5. Seafloor Character, Offshore of Bodega Head Map Area, California

By Mercedes D. Erdey and Guy R. Cochrane

Sheet 6. Ground-Truth Studies, Offshore of Bodega Head Map Area, California

By Nadine E. Golden, Guy R. Cochrane, and Lisa M. Krigsman

Sheet 7. Potential Marine Benthic Habitats, Offshore of Bodega Head Map Area, California

By Bryan E. Dieter, H. Gary Greene, Charles A. Endris, and Erik N. Lowe

Sheet 8. Seismic-Reflection Profiles, Offshore of Bodega Head Map Area, California

By Samuel Y. Johnson, Ray W. Sliter, Stephen R. Hartwell, and John L. Chin

Sheet 9. Local (Offshore of Bodega Head Map Area) and Regional (Offshore from Salt Point to Drakes Bay) Shallow-Subsurface Geology and Structure, California

By Samuel Y. Johnson, Stephen R. Hartwell, Janet T. Watt, and Ray W. Sliter

Sheet 10. Offshore and Onshore Geology and Geomorphology, Offshore of Bodega Head Map Area, California

By Samuel Y. Johnson, Stephen R. Hartwell, and Michael W. Manson 


\section{California State Waters Map Series-Offshore of Bodega Head, California}

By Samuel Y. Johnson, ${ }^{1}$ Peter Dartnell, ${ }^{1}$ Nadine E. Golden, ${ }^{1}$ Stephen R. Hartwell, ${ }^{1}$ Mercedes D. Erdey, ${ }^{1}$ H. Gary Greene, ${ }^{2}$ Guy R. Cochrane, ${ }^{1}$ Rikk G. Kvitek, ${ }^{3}$ Michael W. Manson, ${ }^{4}$ Charles A. Endris, ${ }^{2}$ Bryan E. Dieter, ${ }^{2}$ Janet T. Watt, ${ }^{1}$ Lisa M. Krigsman, ${ }^{5}$ Ray W. Sliter, ${ }^{1}$ Erik N. Lowe, ${ }^{1}$ and John L. Chin ${ }^{1}$

(Samuel Y. Johnson ${ }^{1}$ and Susan A. Cochran, ${ }^{1}$ editors)

\section{Preface}

In 2007, the California Ocean Protection Council initiated the California Seafloor Mapping Program (CSMP), designed to create a comprehensive seafloor map of high-resolution bathymetry, marine benthic habitats, and geology within California's State Waters. The program supports a large number of coastal-zone- and ocean-management issues, including the California Marine Life Protection Act (MLPA) (California Department of Fish and Wildlife, 2008), which requires information about the distribution of ecosystems as part of the design and proposal process for the establishment of Marine Protected Areas. A focus of CSMP is to map California's State Waters with consistent methods at a consistent scale.

The CSMP approach is to create highly detailed seafloor maps through collection, integration, interpretation, and visualization of swath sonar bathymetry data (the undersea equivalent of satellite remote-sensing data in terrestrial mapping), acoustic backscatter, seafloor video, seafloor photography, high-resolution seismic-reflection profiles, and bottom-sediment sampling data. The map products display seafloor morphology and character, identify potential marine benthic habitats, and illustrate both the surficial seafloor geology and shallow subsurface geology. It is emphasized that the more interpretive habitat and geology maps rely on the integration of multiple, new high-resolution datasets and that mapping at small scales would not be possible without such data.

This approach and CSMP planning is based in part on recommendations of the Marine Mapping Planning Workshop (Kvitek and others, 2006), attended by coastal and marine managers and scientists from around the state. That workshop established geographic priorities for a coastal mapping project and identified the need for coverage of "lands" from the shore strand line (defined as Mean Higher High Water; MHHW) out to the 3-nautical-mile (5.6-km) limit of California's State Waters. Unfortunately, surveying the zone from MHHW out to 10-m water depth is not consistently possible using ship-based surveying methods, owing to sea state (for example, waves, wind, or currents), kelp coverage, and shallow rock outcrops. Accordingly, some of the maps presented in this series commonly do not cover the zone from the shore out to 10-m depth; these "no data" zones appear pale gray on most maps.

This map is part of a series of online U.S. Geological Survey (USGS) publications, each of which includes several map sheets, some explanatory text, and a descriptive pamphlet. Each map sheet

\footnotetext{
${ }^{1}$ U.S. Geological Survey

${ }^{2}$ Moss Landing Marine Laboratories, Center for Habitat Studies

${ }^{3}$ California State University, Monterey Bay, Seafloor Mapping Lab

${ }^{4}$ California Geological Survey

${ }^{5}$ National Oceanic and Atmospheric Administration, National Marine Fisheries Service
} 
is published as a PDF file. Geographic information system (GIS) files that contain both ESRI ${ }^{6}$ ArcGIS raster grids (for example, bathymetry, seafloor character) and geotiffs (for example, shaded relief) are also included for each publication. For those who do not own the full suite of ESRI GIS and mapping software, the data can be read using ESRI ArcReader, a free viewer that is available at http://www.esri.com/software/arcgis/arcreader/index.html (last accessed March 21, 2014).

The California Seafloor Mapping Program (CSMP) is a collaborative venture between numerous different federal and state agencies, academia, and the private sector. CSMP partners include the California Coastal Conservancy, the California Ocean Protection Council, the California Department of Fish and Wildlife, the California Geological Survey, California State University at Monterey Bay's Seafloor Mapping Lab, Moss Landing Marine Laboratories Center for Habitat Studies, Fugro Pelagos, Pacific Gas and Electric Company, National Oceanic and Atmospheric Administration (NOAA, including National Ocean Service - Office of Coast Surveys, National Marine Sanctuaries, and National Marine Fisheries Service), U.S. Army Corps of Engineers, the Bureau of Ocean Energy Management, the National Park Service, and the U.S. Geological Survey.

\footnotetext{
${ }^{6}$ Environmental Systems Research Institute, Inc.
} 


\title{
Chapter 1. Introduction
}

\author{
By Samuel Y. Johnson
}

\section{Regional Setting}

The map area offshore of Bodega Head, California, which is referred to herein as the "Offshore of Bodega Head" map area (figs. 1-1, 1-2) is located in northern California, about $70 \mathrm{~km}$ north of San Francisco and about $80 \mathrm{~km}$ south of Point Arena. The onshore part of the map area is largely undeveloped, used primarily for recreation, farms and ranches, and a few wineries. The small town of Bodega Bay (population, about 1100), located on the east side of Bodega Harbor, is the largest cultural center (fig. 1-2). The smaller town of Bodega (population, about 220) lies $8 \mathrm{~km}$ east of the coast, near the east edge of the map area. Bodega Harbor is an important commercial fishing base and, in season, an active sport fishing and recreation harbor. Two jetties protect the entrance to the harbor, and a $2.5-\mathrm{km}-$ long navigation channel is maintained through shallow water from the harbor entrance to marinas at the north end of the harbor. The University of California, Davis, Bodega Marine Laboratory is located at Horseshoe Cove on the west (Pacific Ocean) side of Bodega Head. Scenic U.S. Highway 1 trends along the coastline north of the town of Bodega Bay, but it veers to the east away from the coast farther south. Much of the coastline from Bodega Head north to about $6 \mathrm{~km}$ north of the Russian River (fig. 1-1) is part of Sonoma Coast State Park.

The Offshore of Bodega Head map area is cut by the northwest-striking San Andreas Fault, the right-lateral transform boundary between the North American and Pacific plates (figs. 1-1, 1-2). From southeast to northwest, this fault runs through Bodega Bay and Bodega Harbor, crosses the Bodega Head isthmus south of the mouth of Salmon Creek, and extends offshore for about $20 \mathrm{~km}$ before passing onland at Fort Ross, about $10 \mathrm{~km}$ north of the map area. The San Andreas Fault juxtaposes rocks of the Jurassic and Cretaceous Franciscan Complex on the northeast with Cretaceous granitic rocks on the southwest, and it has an estimated slip rate of about 17 to $25 \mathrm{~mm} / \mathrm{yr}$ in this area (U.S. Geological Survey and California Geological Survey, 2010). The devastating great 1906 California earthquake (M7.8) is thought to have nucleated on the San Andreas Fault offshore of San Francisco, about $80 \mathrm{~km}$ south of Bodega Head (see, for example, Bolt, 1968; Lomax, 2005), with the rupture extending northward through the Offshore of Bodega Head map area an additional $220 \mathrm{~km}$, to the south flank of Cape Mendocino.

The San Andreas Fault is an important control on coastal geomorphology. North of the mouth of Salmon Creek (fig. 1-2), the coast and shoreline are rugged and scenic, characterized by flights of uplifted marine terraces, rocky promontories, nearshore sea stacks, kelp-rich coves, and both pocket beaches and longer beach strands, the latter of which include 1.7-km-long Wrights Beach and 500-mlong Portuguese Beach. Failure of steep bluffs underlain by sheared rocks of the Franciscan Complex between Duncans Point and Portuguese Beach has notably destroyed and damaged many homes (Griggs and others, 2005).

The coast has lower relief between the mouth of Salmon Creek and Mussel Point (fig. 1-2), where $4.1-\mathrm{km}$-long South Salmon Creek Beach is backed by a large (about $4 \mathrm{~km}^{2}$ ) complex of coastal sand dunes that reach elevations of $30 \mathrm{~m}$. The enormous volume of sand on the beach and in the dune field is derived by southward littoral drift from the Russian River (5 km north of the map area), Salmon Creek, and smaller coastal watersheds. The sediment is trapped by protruding bedrock at Mussel Point, which represents the south end of the Russian River littoral cell (Habel and Armstrong, 1978). Hapke and others (2006) indicated that South Salmon Creek Beach has been accreting at rates of 0 to $0.5 \mathrm{~m} / \mathrm{yr}$ over the long term (1862 to 2002) and 0 to $1.3 \mathrm{~m} / \mathrm{yr}$ over the short term (1952 to 2002). 
Bodega Head, on the west side of the San Andreas Fault, is underlain by Cretaceous granitic rocks, and its shoreline is variously characterized by relatively low-lying terraces, steep and high (as much as $65 \mathrm{~m}$ ) bluffs, and a few pocket beaches. Hapke and Reid (2007) documented Bodega Head cliff retreat from 1929 to 2002 of as much as $55 \mathrm{~m}$, at rates ranging from about 0.1 to $0.6 \mathrm{~m} / \mathrm{yr}$. East of Bodega Head, Doran Beach (part of Doran Regional Park) is a 1.7-km-long sand spit that forms the north boundary of Bodega Bay and the south boundary of Bodega Harbor.

The coast south of Doran Beach on the east flank of Bodega Bay is composed of rocky bluffs, hummocky marine terraces, and a few small pocket beaches. The bluffs are underlain by sheared rocks of the Franciscan Complex and are highly susceptible to landslides; Hapke and Reid (2007) documented cliff retreat from 1929 to 2002 of as much as $43 \mathrm{~m}$, at rates ranging from about 0.1 to $0.4 \mathrm{~m} / \mathrm{yr}$. This section of coast includes two prominent watersheds that have protected coastal estuaries, Estero Americano (15-km-long, 127-km² drainage basin) and Estero de San Antonio (9.5-km-long, 129-km² drainage basin), which drain westward into Bodega Bay (fig. 1-2).

The offshore part of the Offshore of Bodega Head map area is characterized by an extensive, rugged and rocky shelf (fig. 1-2) underlain by Cretaceous granitic rocks. This rocky terrain, centered offshore of Bodega Head, extends northwestward for about $15 \mathrm{~km}$, from the south edge of the map area (where it forms the west boundary of Bodega Bay) to the northern-central part of the map area offshore of the mouth of Salmon Creek. This rocky seafloor reaches water depths of 40 to $80 \mathrm{~m}$ and is overlain by young sediment. Both the rocky seafloor and the smooth, sediment-covered parts of the shelf dip offshore about $0.7^{\circ}$ to $0.8^{\circ}$.

Circulation over the shelf and seafloor in the map area (and in the broader central California region) is dominated by the southward-flowing California Current, the eastern boundary current of the North Pacific Gyre (Hickey, 1979). Associated upwelling brings cool, nutrient-rich waters to the surface, resulting in high biological productivity. Persistent northwest winds are sometimes weak or absent during the fall and winter, causing the California Current to move farther offshore so that the shelf is affected by the Davidson Current, a weaker northward-flowing countercurrent (Hickey, 1979). As a result, net flow over the continental shelf is commonly southeastward during the spring and summer and northwestward during the fall and winter.

Throughout the year, this part of the northern California coast is exposed to four wave climate regimes: the north Pacific swell, the southern swell, northwest wind waves, and local wind waves (Storlazzi and Griggs, 2000; Storlazzi and Wingfield, 2005). The north Pacific swell dominates in winter months (typically November through March), with wave heights at offshore buoys that range from 2 to $10 \mathrm{~m}$ and wave periods that range from 10 to $25 \mathrm{~s}$ (Storlazzi and Wingfield, 2005). During summer months, the largest waves come from the southern swell, generated by storms in the south Pacific and offshore of Central America. Characteristically, these swells have smaller wave heights (0.3 to $3 \mathrm{~m}$ ) and similarly long periods (from 10 to $25 \mathrm{~s}$ ). Northwest wind waves affect the coast throughout the year, whereas local wind waves are most common from October to April. These two wind-wave regimes typically have wave heights of 1 to $4 \mathrm{~m}$ and short periods of 3 to $10 \mathrm{~s}$.

Potential marine benthic habitats in the Offshore of Bodega Head map area include unconsolidated continental-shelf sediments, mixed continental-shelf substrate, and hard continental-shelf substrate. Rocky-shelf outcrops and rubble are considered to be promising potential habitats for rockfish (Sebastes spp.) and lingcod (Ophiodon elongatus) (Cass and others, 1990; Love and others, 2002), both of which are recreationally and commercially important species.

The Offshore of Bodega Head map area includes two California Marine Protected Areas (California Department of Fish and Wildlife, 2012), the Bodega Head State Marine Reserve and the northern part of the Bodega Head State Marine Conservation Area (fig. 1-2). Additionally, the inland parts of two large estuaries in the map area, Estero Americano and Estero de San Antonio, have been designated as State Marine Recreational Management Areas (fig. 1-2). 


\section{Publication Summary}

This publication about the Offshore of Bodega Head map area includes ten map sheets that contain explanatory text, in addition to this descriptive pamphlet and a data catalog of geographic information system (GIS) files. Sheets 1, 2, and 3 combine data from four different sonar surveys to generate comprehensive high-resolution bathymetry and acoustic-backscatter coverage of the map area. These data reveal a range of physiographic features (highlighted in the perspective views on sheet 4) such as massive, granitic bedrock outcrops, smooth sediment-covered seafloor, and sediment lobes inferred to have formed by ground failure associated with strong ground motions on the nearby San Andreas Fault. To validate geological and biological interpretations of the sonar data shown in sheets 1 , 2, and 3, the U.S. Geological Survey towed a camera sled over specific offshore locations, collecting both video and photographic imagery; this "ground-truth" surveying data is summarized on sheet 6. Sheet 5 is a "seafloor character" map, which classifies the seafloor on the basis of depth, slope, rugosity (ruggedness), and backscatter intensity and which is further informed by the ground-truth-survey imagery. Sheet 7 is a map of "potential habitats," which are delineated on the basis of substrate type, geomorphology, seafloor process, or other attributes that may provide a habitat for a specific species or assemblage of organisms. Sheet 8 compiles representative seismic-reflection profiles from the map area, providing information on the subsurface stratigraphy and structure of the map area. Sheet 9 shows the distribution and thickness of young sediment (deposited over the last about 21,000 years, during the most recent sea-level rise) in both the map area and the larger Salt Point to Drakes Bay region, interpreted on the basis of the seismic-reflection data, and it identifies the Offshore of Bodega Head map area as lying within the Bodega Head-Tomales Point shelf and the Russian River delta and mud belt domains. Sheet 10 is a geologic map that merges onshore geologic mapping (compiled from existing maps by the California Geological Survey) and new offshore geologic mapping that is based on the integration of high-resolution bathymetry and backscatter imagery (sheets 1, 2, 3), seafloor-sediment and rock samples (Reid and others, 2006), digital camera and video imagery (sheet 6), and highresolution seismic-reflection profiles (sheet 8).

The information provided by the map sheets, pamphlet, and data catalog have a broad range of applications. High-resolution bathymetry, acoustic backscatter, ground-truth-surveying imagery, and habitat mapping all contribute to habitat characterization and ecosystem-based management by providing essential data for delineation of marine protected areas and ecosystem restoration. Many of the maps provide high-resolution baselines that will be critical for monitoring environmental change associated with climate change, coastal development, or other forcings. High-resolution bathymetry is a critical component for modeling coastal flooding caused by storms and tsunamis, as well as inundation associated with longer term sea-level rise. Seismic-reflection and bathymetric data help characterize earthquake and tsunami sources, critical for natural-hazard assessments of coastal zones. Information on sediment distribution and thickness is essential to the understanding of local and regional sediment transport, as well as the development of regional sediment-management plans. In addition, siting of any new offshore infrastructure (for example, pipelines, cables, or renewable-energy facilities) will depend on high-resolution mapping. Finally, this mapping will both stimulate and enable new scientific research and also raise public awareness of, and education about, coastal environments and issues. 


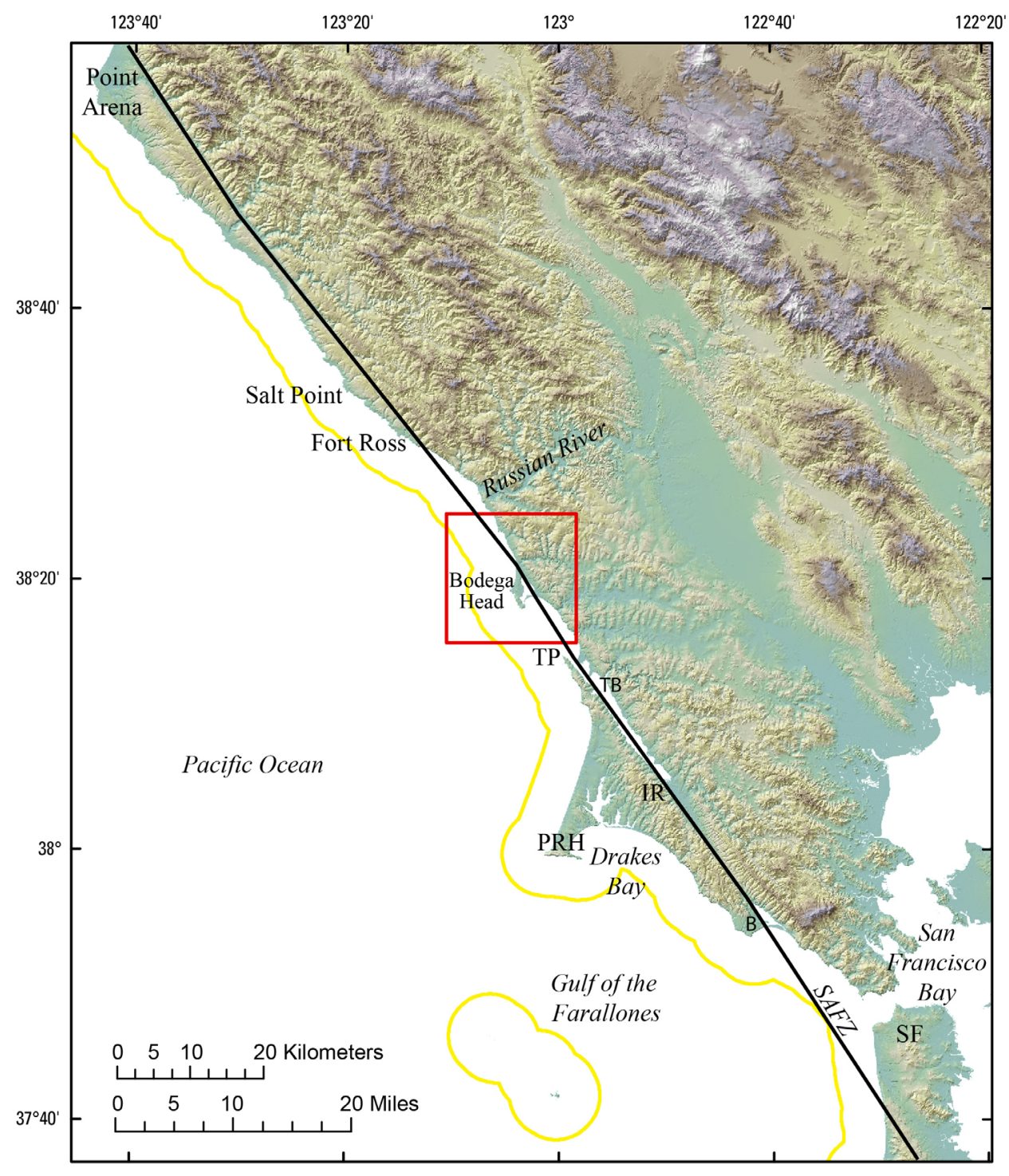

Figure 1-1. Physiography of northern California coast from Point Arena to San Francisco (SF). Red box shows Offshore of Bodega Head map area. Yellow line shows limit of California's State Waters. Black line shows San Andreas Fault Zone (SAFZ). Other abbreviations: B, Bolinas; PRH, Point Reyes headland; SF, San Francisco; TB, Tomales Bay; TP, Tomales Point. 


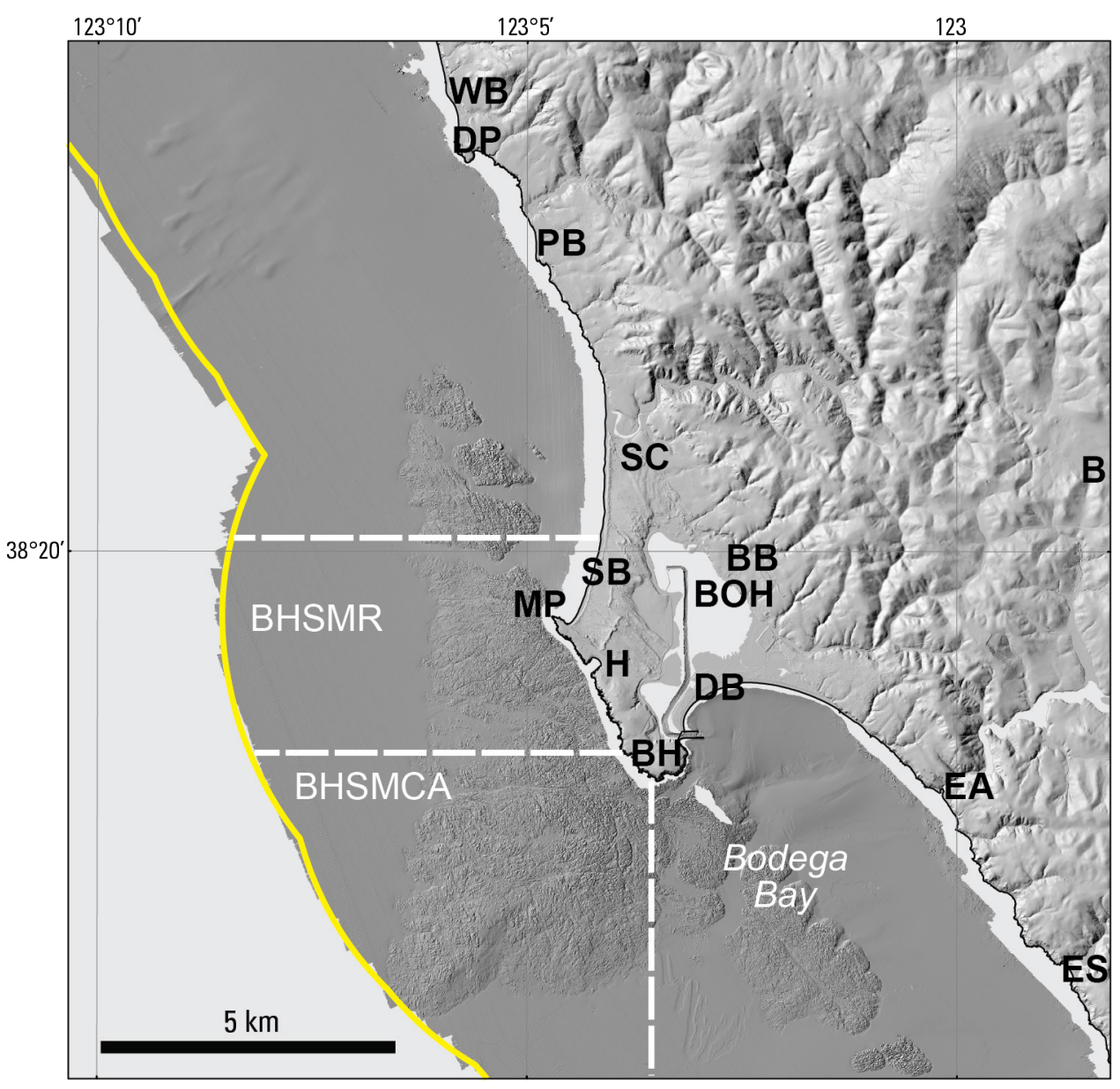

Figure 1-2. Coastal geography of Offshore of Bodega Head map area. Yellow line shows limit of California's State Waters. Dashed white lines show boundaries of offshore California Marine Protected Areas: BHSMCA, Bodega Head State Marine Conservation Area; BHSMR, Bodega Head State Marine Reserve. Other abbreviations: B, town of Bodega; BB, town of Bodega Bay; BH, Bodega Head; BOH, Bodega Harbor; DB, Doran Beach; DP, Duncans Point; EA, Estero Americano; ES, Estero de San Antonio; H, Horseshoe Cove; MP, Mussel Point; PB, Portuguese Beach; SB, South Salmon Creek Beach; SC, Salmon Creek, WB, Wrights Beach. 


\title{
Chapter 2. Bathymetry and Backscatter-Intensity Maps of the Offshore of Bodega Head Map Area (Sheets 1, 2, and 3)
}

\author{
By Peter Dartnell and Rikk G. Kvitek
}

The colored shaded-relief bathymetry (sheet 1), the shaded-relief bathymetry (sheet 2), and the acoustic-backscatter (sheet 3) maps of the Offshore of Bodega Head map area in northern California were generated from bathymetry and backscatter data collected by Fugro Pelagos and by California State University, Monterey Bay (CSUMB) (fig. 1 on sheets 1, 2, 3). Mapping was completed between 2007 and 2010, using a combination of 200-kHz and 400-kHz Reson 7125 and 244-kHz Reson 8101 multibeam echosounders, as well as a $468-\mathrm{kHz}$ SEA SWATHplus bathymetric sidescan-sonar system. These mapping missions combined to collect both bathymetry (sheets 1,2) and acoustic-backscatter data (sheet 3) from about the 10-m isobath to beyond the 3-nautical-mile limit of California's State Waters.

During the mapping missions, an Applanix POS MV (Position and Orientation System for Marine Vessels) was used to accurately position the vessels during data collection, and it also accounted for vessel motion such as heave, pitch, and roll (position accuracy, $\pm 2 \mathrm{~m}$; pitch, roll, and heading accuracy, $\pm 0.02^{\circ}$; heave accuracy, $\pm 5 \%$, or $5 \mathrm{~cm}$ ). To account for tidal-cycle fluctuations, CSUMB used NavCom 2050 GPS receiver (CNAV) data, and Fugro Pelagos used KGPS data (GPS data with realtime kinematic corrections); in addition, sound-velocity profiles were collected with an Applied Microsystems (AM) SVPlus sound velocimeter. Soundings were corrected for vessel motion using the Applanix POS MV data, for variations in water-column sound velocity using the AM SVPlus data, and for variations in water height (tides) using vertical-position data from the KGPS receivers.

The multibeam-echosounder backscatter data were postprocessed using CARIS 7.0/Geocoder software. Within Geocoder, the backscatter intensities were radiometrically corrected (including despeckling and angle-varying gain adjustments), and the position of each acoustic sample was geometrically corrected for slant range on a line-by-line basis. After the lines were corrected, they were mosaicked into 1- or 2-m-resolution images. Overlap between parallel lines was resolved using a priority table whose values were based on the distance of each sample from the ship track, with the samples that were closest to and furthest from the ship track being given the lowest priority. An antialiasing algorithm was also applied. The mosaics were then exported as georeferenced TIFF images, imported into a geographic information system (GIS), and converted to GRIDs at 2-m resolution.

The SWATHplus backscatter data were postprocessed using USGS software (D.P. Finlayson, written commun., 2011) that normalizes for time-varying signal loss and beam-directivity differences. Thus, the raw 16-bit backscatter data were gain-normalized to enhance the backscatter of the SWATHplus system. The resulting normalized-amplitude values were rescaled to 16-bit and gridded into GeoJPEGs using GRID Processor Software, then imported into a GIS and converted to GRIDs.

Processed soundings from the different mapping missions were exported from the acquisition or processing software as XYZ files and bathymetric surfaces. All the surfaces were merged into one overall 2-m-resolution bathymetric-surface model and clipped to the boundary of the map area. An illumination having an azimuth of $300^{\circ}$ and from $45^{\circ}$ above the horizon was then applied to the bathymetric surface to create the shaded-relief imagery (sheets 1,2). In addition, a modified "rainbow" color ramp was applied to the bathymetry data for sheet 1, using reds and oranges to represent shallower depths, and purples to represent greater depths (note that the Offshore of Bodega Head map area requires only the shallower part of the full-rainbow color ramp used on some of the other maps in the California State Waters Map Series; see, for example, Kvitek and others, 2012). This colored bathymetry surface was draped over the shaded-relief imagery at 60-percent transparency to create a colored shaded-relief map (sheet 1). Note that the ripple patterns and straight lines that are apparent 
within the map area are data-collection artifacts. In addition, lines at the borders of some surveys are the result of slight differences in depth, as measured by different mapping systems in different years. These various artifacts are made obvious by the hillshading process.

Bathymetric contours (sheets $1,2,3,5,7,10$ ) were generated at 10 -m intervals from the merged 2-m-resolution bathymetric surface. The merged surface was smoothed using the Focal Mean tool in ArcGIS and a circular neighborhood that has a radius of between 20 and $30 \mathrm{~m}$ (depending on the location). The contours were generated from this smoothed surface using the Spatial Analyst Contour tool in ArcGIS. The most continuous contour segments were preserved; smaller segments and isolated island polygons were excluded from the final output. The contours were then clipped to the boundary of the map area.

The acoustic-backscatter imagery from each different mapping system and processing method were merged into their own individual grids. These individual grids, which cover different areas, were displayed in a GIS to create a composite acoustic-backscatter map (sheet 3). On the map, brighter tones indicate higher backscatter intensity, and darker tones indicate lower backscatter intensity. The intensity represents a complex interaction between the acoustic pulse and the seafloor, as well as characteristics within the shallow subsurface, providing a general indication of seafloor texture and sediment type. Backscatter intensity depends on the acoustic source level; the frequency used to image the seafloor; the grazing angle; the composition and character of the seafloor, including grain size, water content, bulk density, and seafloor roughness; and some biological cover. Harder and rougher bottom types such as rocky outcrops or coarse sediment typically return stronger intensities (high backscatter, lighter tones), whereas softer bottom types such as fine sediment return weaker intensities (low backscatter, darker tones). The differences in backscatter intensity that are apparent in some areas on sheet 3 are due to the different frequencies of the mapping systems, as well as different processing techniques. Linear features of higher backscatter intensity throughout the map area are data-collection artifacts.

The onshore-area image was generated by applying an illumination having an azimuth of $300^{\circ}$ and from $45^{\circ}$ above the horizon to 2-m-resolution topographic-lidar data from California Coastal Conservancy (available at http://www.csc.noaa.gov/digitalcoast/data/coastallidar/) and to 10-mresolution data from the U.S. Geological Survey's National Elevation Dataset (available at http://ned.usgs.gov/). 


\title{
Chapter 3. Data Integration and Visualization for the Offshore of Bodega Head Map Area (Sheet 4)
}

\author{
By Peter Dartnell
}

Mapping California's State Waters has produced a vast amount of acoustic and visual data, including bathymetry, acoustic backscatter, seismic-reflection profiles, and seafloor video and photography. These data are used by researchers to develop maps, reports, and other tools to assist in the coastal and marine spatial-planning capability of coastal-zone managers and other stakeholders. For example, seafloor-character (sheet 5), habitat (sheet 7), and geologic (sheet 10) maps of the Offshore of Bodega Head map area may assist in the designation of Marine Protected Areas, as well as in their monitoring. These maps and reports also help to analyze environmental change owing to sea-level rise and coastal development, to model and predict sediment and contaminant budgets and transport, to site offshore infrastructure, and to assess tsunami and earthquake hazards. To facilitate this increased understanding and to assist in product development, it is helpful to integrate the different datasets and then view the results in three-dimensional representations such as those displayed on the data integration and visualization sheet for the Offshore of Bodega Head map area (sheet 4).

The maps and three-dimensional views on sheet 4 were created using a series of geographic information systems (GIS) and visualization techniques. Using GIS, the bathymetric and topographic data (sheet 1) were converted to ASCIIRASTER format files, and the acoustic-backscatter data (sheet 3) were converted to geoTIFF images. The bathymetric and topographic data were imported in the Fledermaus ${ }^{\circledR}$ software (QPS). The bathymetry was color-coded to closely match the colored shadedrelief bathymetry on sheet 1 , in which reds and oranges represent shallower depths and purples represent deeper depths. Topographic data were shown in gray shades. The acoustic-backscatter geoTIFF images were also draped over the bathymetry data. The colored bathymetry, topography, and draped backscatter were then tilted and panned to create the perspective views such as those shown in figures $1,2,4,5$, and 6 on sheet 4 . These figures highlight the seafloor morphology in the Offshore of Bodega Head map area, which includes outcrops of fractured bedrock and complex patterns of offshore sediment lobes.

Video-mosaic images created from digital seafloor video (for example, fig. 3 on sheet 4) display the geologic complexity (rock, sand, and mud; see sheet 10) and biologic complexity of the seafloor. Whereas photographs capture high-quality snapshots of smaller areas of the seafloor (see sheet 6), video mosaics capture larger areas and can show transition zones between seafloor environments. Digital seafloor video is collected from a camera sled towed approximately 1 to 2 meters over the seafloor, at speeds less than 1 nautical mile/hour. Using standard video-editing software, as well as software developed at the Center for Coastal and Ocean Mapping, University of New Hampshire, the digital video is converted to AVI format, cut into 2-minute sections, and desampled to every second or third frame. The frames are merged together using pattern-recognition algorithms from one frame to the next and converted to a TIFF image. The images are then rectified to the bathymetry data using ship navigation recorded with the video and layback estimates of the towed camera sled.

Block diagrams that combine the bathymetry with seismic-reflection-profile data help integrate surface and subsurface observations, especially stratigraphic and structural relations (for example, fig. 6 on sheet 4). These block diagrams were created by converting digital seismic-reflection-profile data (see sheet 8 ) into TIFF images, while taking note of the starting and ending coordinates and maximum and minimum depths. The images were then imported into the Fledermaus ${ }^{\circledR}$ software as vertical images and merged with the bathymetry imagery. 


\title{
Chapter 4. Seafloor-Character Map of the Offshore of Bodega Head Map Area (Sheet 5)
}

\author{
By Mercedes D. Erdey and Guy R. Cochrane
}

The California State Marine Life Protection Act (MLPA) calls for protecting representative types of habitat in different depth zones and environmental conditions. A science team, assembled under the auspices of the California Department of Fish and Wildlife (CDFW), has identified seven substratedefined seafloor habitats in California's State Waters that can be classified using sonar data and seafloor video and photography. These habitats include rocky banks, intertidal zones, sandy or soft ocean bottoms, underwater pinnacles, kelp forests, submarine canyons, and seagrass beds. The following five depth zones, which determine changes in species composition, have been identified: Depth Zone 1, intertidal; Depth Zone 2, intertidal to $30 \mathrm{~m}$; Depth Zone 3, 30 to $100 \mathrm{~m}$; Depth Zone 4, 100 to $200 \mathrm{~m}$; and Depth Zone 5, deeper than $200 \mathrm{~m}$ (California Department of Fish and Wildlife, 2008). The CDFW habitats, with the exception of depth zones, can be considered a subset of a broader classification scheme of Greene and others (1999) that has been used by the U.S. Geological Survey (USGS) (Cochrane and others, 2003, 2005). These seafloor-character maps are generalized polygon shapefiles that have attributes derived from Greene and others (2007).

A 2007 Coastal Map Development Workshop, hosted by the USGS in Menlo Park, California, identified the need for more detailed (relative to Greene and others' [1999] attributes) raster products that preserve some of the transitional character of the seafloor when substrates are mixed and (or) they change gradationally. The seafloor-character map, which delineates a subset of the CDFW habitats, is a GIS-derived raster product that can be produced in a consistent manner from data of variable quality covering large geographic regions.

The following four substrate classes are identified in the Offshore of Bodega Head map area:

- Class I: Fine- to medium-grained smooth sediment

- Class II: Mixed smooth sediment and rock

- Class III: Rock and boulder, rugose

- Class IV: Medium- to coarse-grained sediment (in scour depressions)

The seafloor-character map of the Offshore of Bodega Head map area (sheet 5) was produced using video-supervised maximum-likelihood classification of the bathymetry and intensity of return from sonar systems, following the method described by Cochrane (2008). The two variants used in this classification were backscatter intensity and derivative rugosity. The rugosity calculation was performed using the Terrain Ruggedness (VRM) tool within the Benthic Terrain Modeler toolset v. 3.0 (Wright and others, 2012; available at http://esriurl.com/5754).

Class I, II, and III values were delineated using multivariate analysis. Class IV (medium- to coarse-grained sediment, in scour depressions) values were determined on the basis of their visual characteristics using both shaded-relief bathymetry and backscatter (slight depression in the seafloor, very high backscatter return). The resulting map (gridded at $2 \mathrm{~m}$ ) was cleaned by hand to remove datacollection artifacts (for example, the trackline nadir).

On the seafloor-character map (sheet 5), the four substrate classes have been colored to indicate the California MLPA depth zones and the Coastal and Marine Ecological Classification Standard (CMECS) slope zones (Madden and others, 2008) in which they belong. The California MLPA depth zones are Depth Zone 1 (intertidal), Depth Zone 2 (intertidal to $30 \mathrm{~m}$ ), Depth Zone 3 (30 to $100 \mathrm{~m}$ ), Depth Zone 4 (100 to $200 \mathrm{~m}$ ), and Depth Zone 5 (greater than $200 \mathrm{~m}$ ); in the Offshore of Bodega Head map area, only Depth Zones 2 and 3 are present. The slope classes that represent the CMECS slope 
zones are Slope Class $1=$ flat $\left(0^{\circ}\right.$ to $\left.5^{\circ}\right)$, Slope Class $2=$ sloping $\left(5^{\circ}\right.$ to $\left.30^{\circ}\right)$, Slope Class $3=$ steeply sloping $\left(30^{\circ}\right.$ to $\left.60^{\circ}\right)$, Slope Class $4=$ vertical $\left(60^{\circ}\right.$ to $\left.90^{\circ}\right)$, and Slope Class $5=$ overhang (greater than $90^{\circ}$ ); in the Offshore of Bodega Head map area, only Slope Classes 1 and 2 are present. The final classified seafloor-character raster map image has been draped over the shaded-relief bathymetry for the area (sheets 1 and 2) to produce the image shown on the seafloor-character map on sheet 5.

The seafloor-character classification also is summarized on sheet 5 in table 1. Fine- to mediumgrained smooth sediment (sand and mud) makes up 69.3 percent $\left(96.2 \mathrm{~km}^{2}\right.$ ) of the map area: 22.7 percent $\left(31.5 \mathrm{~km}^{2}\right)$ is in Depth Zone 2, and 46.6 percent $\left(64.7 \mathrm{~km}^{2}\right)$ is in Depth Zone 3. Mixed smooth sediment (sand and gravel) and rock (that is, sediment typically forming a veneer over bedrock, or rock outcrops having little to no relief) make up 13.5 percent $\left(18.7 \mathrm{~km}^{2}\right)$ of the map area: 4.2 percent $(5.8$ $\mathrm{km}^{2}$ ) is in Depth Zone 2, and 9.3 percent $\left(12.9 \mathrm{~km}^{2}\right.$ ) is in Depth Zone 3. Rock and boulder, rugose (rock and boulder outcrops having high surficial complexity) makes up 15.2 percent $\left(21.2 \mathrm{~km}^{2}\right)$ of the map area: 8.6 percent $\left(12.0 \mathrm{~km}^{2}\right)$ is in Depth Zone 2, and 6.6 percent $\left(9.2 \mathrm{~km}^{2}\right)$ is in Depth Zone 3. Mediumto coarse-grained sediment (in scour depressions consisting of material that is coarser than the surrounding seafloor) makes up 2.0 percent $\left(2.7 \mathrm{~km}^{2}\right)$ of the map area: 1.2 percent $\left(1.6 \mathrm{~km}^{2}\right)$ is in Depth Zone 2 , and 0.8 percent $\left(1.1 \mathrm{~km}^{2}\right)$ is in Depth Zone 3 .

A small number of video observations were used to supervise the numerical classification of the seafloor. All video observations (see sheet 6) are used for accuracy assessment of the seafloor-character map after classification. To compare observations to classified pixels, each observation point is assigned a class (I, II, or III), according to the visually derived, major or minor geologic component (for example, sand or rock) and the abiotic complexity (vertical variability) of the substrate recorded during groundtruth surveys (table 4-1; see also, chapter 5 of this pamphlet). Class IV values were assigned on the basis of the observation of one or more of a group of features that includes both larger scale bedforms (for example, sand waves), as well as sediment-filled scour depressions that resemble the "rippled scour depressions" of Cacchione and others (1984) and Phillips and others (2007) and also the "sorted bedforms" of Murray and Thieler (2004), Goff and others (2005), and Trembanis and Hume (2011). On the geologic map (see sheet 10 of this report), they are referred to as "marine shelf scour depressions."

Next, circular buffer areas were created around individual observation points using a 10-m radius to account for layback and positional inaccuracies inherent to the towed-camera system. The radius length is an average of the distances between the positions of sharp interfaces seen on both the video (the position of the ship at the time of observation) and sonar data, plus the distance covered during a 10 -second observation period at an average speed of 1 nautical mile/hour. Each buffer, which covers more than $300 \mathrm{~m}^{2}$, contains approximately 77 pixels. The classified (I, II, III) buffer is used as a mask to extract pixels from the seafloor-character map. These pixels are then compared to the class of the buffer. For example, if the shipboard-video observation is Class II (mixed smooth sediment and rock), but 12 of the 77 pixels within the buffer area are characterized as Class I (fine- to medium-grained smooth sediment), and 15 (of the 77) are characterized as Class III (rock and boulder, rugose), then the comparison would be "Class I, 12; Class II, 50; Class III, 15" (fig. 4-1). If the video observation of substrate is Class II, then the classification is accurate because the majority of seafloor pixels in the buffer are Class II. The accuracy values in table 4-2 represent the final of several classification iterations aimed at achieving the best accuracy, given the variable quality of sonar data (see discussion in Cochrane, 2008) and the limited ground-truth information available when compared to the continuous coverage provided by swath sonar. Presence/absence values in table 4-2 reflect the percentages of observations where the sediment classification of at least one pixel within the buffer zone agreed with the observed sediment type at a certain location.

The seafloor in the Offshore of Bodega Head map area is covered predominantly by Class I sediment composed of sand and mud. Several large exposures of rugose bedrock (Class III) dominate the central-southern part of the map area, offshore of Horseshoe Cove (fig. 1-2). The rock outcrops are 
covered with varying thickness of fine (Class I) to coarse (Class II) sediment. Several areas of mediumto coarse-grained scour depressions (Class IV) have also been mapped adjacent to the rock outcrops. The mapped part of the entrance to Bodega Harbor is dominated by large sand waves made up of coarseto medium-grained sand (Class IV) and fine sand and mud (Class I).

The classification accuracies of Class I, III, and IV sediments $(65,77$, and 71 percent accurate, respectively; table 4-2) are determined by comparing the shipboard video observations and the classified map. The weaker agreement in Class II (40 percent accurate) likely is due to the relatively narrow and intermittent nature of transition zones from sediment to rock, the size of the buffer, and the limited number of observations (20 video points) over this sediment class. The bedrock outcrops in this area are composed of differentially eroded sedimentary rocks (Cochrane and Lafferty, 2002). Erosion of softer layers produces Class I and II sediments, resulting in patchy areas of rugose rock and boulder habitat (Class III) on the seafloor. A single buffered observation locale of 78 pixels, therefore, is likely to be interspersed with other classes of pixels, in addition to Class III. Percentages for presence/absence within a buffer also were calculated as a better measure of the accuracy of the classification for patchy rock habitat. The presence/absence accuracy was found to be significant for all classes (77 percent for Class I, 90 percent for Class II, 99 percent for Class III, and 90 percent for Class IV).
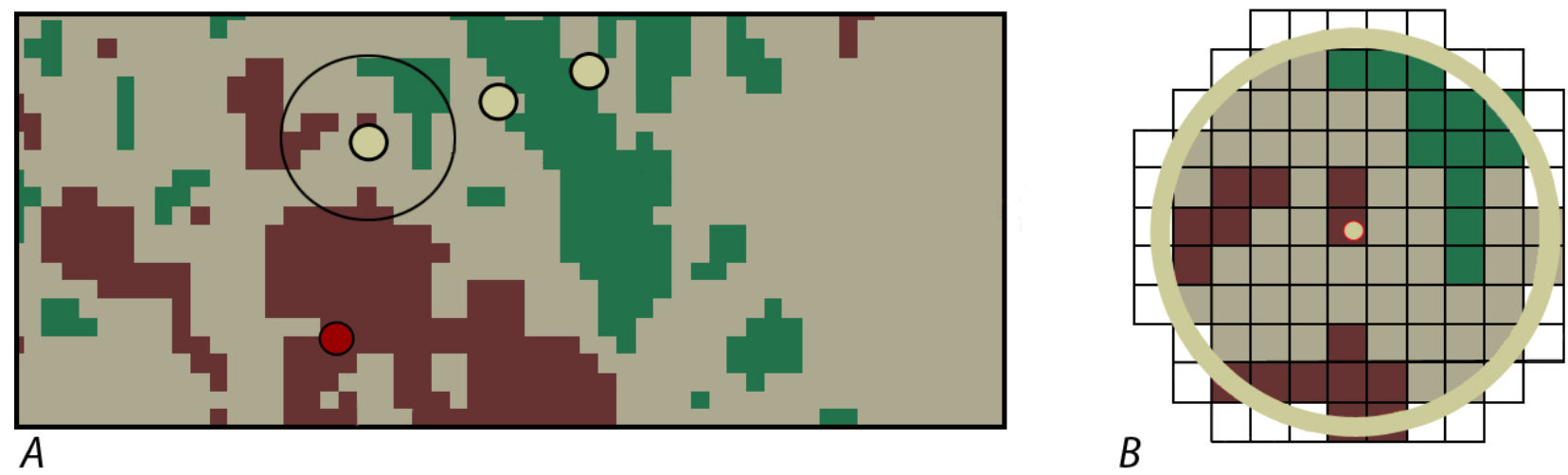

Figure 4-1. Detailed view of ground-truth data, showing accuracy-assessment methodology. $A$, Dots illustrate ground-truth observation points, each of which represents 10-second window of substrate observation plotted over seafloor-character grid; circle around dot illustrates area of buffer depicted in $B$. $B$, Pixels of seafloorcharacter data within 10-m-radius buffer centered on one individual ground-truth video observation. 
Table 4-1. Conversion table showing how video observations of primary substrate (more than 50 percent seafloor coverage), secondary substrate (more than 20 percent seafloor coverage), and abiotic seafloor complexity (in first three columns) are grouped into seafloor-character-map Classes I, II, III, and IV for use in supervised classification and accuracy assessment in Offshore Bodega Head map area.

[In areas of low visibility where primary and secondary substrate could not be identified with confidence, recorded observations of substrate (in fourth column) were used to assess accuracy]

\begin{tabular}{|c|c|c|c|}
\hline Primary-substrate component & Secondary-substrate component & Abiotic seafloor complexity & $\begin{array}{l}\text { Low-visibility } \\
\text { observations }\end{array}$ \\
\hline \multicolumn{4}{|c|}{ Class I } \\
\hline mud & sand & low & \\
\hline sand & mud & low & \\
\hline \multirow[t]{4}{*}{ sand } & sand & low & \\
\hline & & & sediment \\
\hline & & & mud component \\
\hline & & & ripples \\
\hline \multicolumn{4}{|c|}{ Class II } \\
\hline boulders & cobbles & low & \\
\hline boulders & sand & low & \\
\hline rock & rock & low & \\
\hline sand & rock & low & \\
\hline sand & rock & $\bmod$ & \\
\hline \multicolumn{4}{|c|}{ Class III } \\
\hline boulders & boulders & moderate & \\
\hline boulders & rock & moderate & \\
\hline boulders & rock & high & \\
\hline boulders & sand & moderate & \\
\hline rock & boulders & moderate & \\
\hline rock & boulders & high & \\
\hline rock & cobbles & moderate & \\
\hline rock & rock & moderate & \\
\hline rock & rock & high & \\
\hline rock & sand & moderate & \\
\hline \multicolumn{4}{|c|}{ Class IV } \\
\hline sand & sand & low & \\
\hline & & & megaripples \\
\hline & & & $\begin{array}{l}\text { oscillatory } \\
\text { megaripples }\end{array}$ \\
\hline & & & depression \\
\hline
\end{tabular}


Table 4-2. Accuracy-assessment statistics for seafloor-character-map classifications in Offshore of Bodega Head map area.

[Accuracy assessments are based on video observations]

\begin{tabular}{|l|c|c|c|}
\hline \multicolumn{1}{|c|}{ Class } & Number of observations & \% majority & \% presence/absence \\
\hline I-Fine- to medium-grained smooth sediment & 106 & 64.5 & 77.4 \\
\hline II-Mixed smooth sediment and rock & 20 & 39.7 & 90.0 \\
\hline III-Rock and boulder, rugose & 136 & 77.0 & 98.5 \\
\hline IV-Medium- to coarse-grained sediment (in scour depressions) & 10 & 70.7 & 90.0 \\
\hline
\end{tabular}




\title{
Chapter 5. Ground-Truth Studies for the Offshore of Bodega Head Map Area (Sheet 6)
}

\author{
By Nadine E. Golden and Guy R. Cochrane
}

To validate the interpretations of sonar data in order to turn it into geologically and biologically useful information, the U.S. Geological Survey (USGS) towed a camera sled (fig. 5-1) over specific locations throughout the Offshore of Bodega Head map area to collect video and photographic data that would "ground truth" the seafloor. This ground-truth surveying occurred in 2008. The camera sled was towed 1 to $2 \mathrm{~m}$ above the seafloor at speeds of between 1 and 2 nautical miles/hour. Ground-truth surveys in this map area include approximately 6 trackline kilometers of video and 381 still photographs, in addition to 351 seafloor observations of abiotic and biotic attributes. A visual estimate of slope also was recorded.

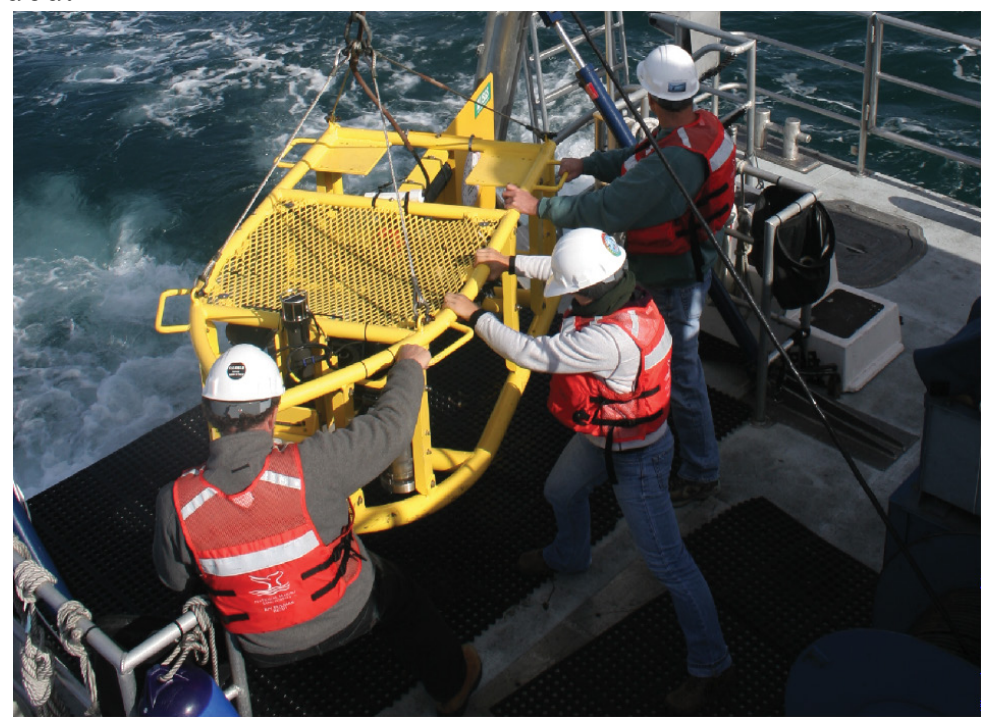

Figure 5-1. Photograph of camera sled used in USGS 2008 ground-truth survey.

During the cruise, the USGS camera sled housed two standard-definition $(640 \times 480$ pixel resolution) video cameras (one forward looking, and one downward looking), a high-definition $(1,080 \times 1,920$ pixel resolution) video camera, and an 8-megapixel digital still camera. During this cruise, in addition to recording the seafloor characteristics, a digital still photograph was captured once every 30 seconds.

The camera-sled tracklines (shown by colored dots on the map on sheet 6) are sited in order to visually inspect areas representative of the full range of bottom hardness and rugosity in the map area. The video is fed in real time to the research vessel, where USGS and National Oceanic and Atmospheric Administration (NOAA) scientists record both the geologic and biologic character of the seafloor. While the camera is deployed, several different observations are recorded for a 10-second period once every minute, using the protocol of Anderson and others (2007). Observations of primary substrate, secondary substrate, slope, abiotic complexity, biotic complexity, and biotic cover are mandatory. Observations of key geologic features and the presence of key species also are made.

Primary and secondary substrate, by definition, constitute greater than 50 and 20 percent of the seafloor, respectively, during an observation. The grain-size values that differentiate the substrate classes are based on the Wentworth (1922) scale, and the sand, cobble, and boulder sizes are classified as in Wentworth (1922). However, the difficulty in distinguishing the finest divisions in the Wentworth 
(1922) scale during video observations made it necessary to aggregate some grain-size classes, as was done in the Anderson and others (2007) methodology: the granule and pebble sizes have been grouped together into a class called "gravel," and the clay and silt sizes have been grouped together into a class called "mud." In addition, hard bottom and clasts larger than boulder size are classified as "rock." Benthic-habitat complexity, which is divided into abiotic (geologic) and biotic (biologic) components, refers to the visual classification of local geologic features and biota that potentially can provide refuge for both juvenile and adult forms of various species (Tissot and others, 2006).

Sheet 6 contains a smaller, simplified (depth-zone symbology has been removed) version of the seafloor-character map on sheet 5. On this simplified map, the camera-sled tracklines used to groundtruth-survey the sonar data are shown by aligned colored dots, each dot representing the location of a recorded observation. A combination of the abiotic attributes (primary- and secondary-substrate compositions), as well as vertical variability, were used to derive the different classes represented on the seafloor-character map (sheet 5); on the simplified map, the derived classes are represented by colored dots. Also on this map are locations of the detailed views of seafloor character, shown by boxes (Boxes A through C); for each view, the box shows the locations (indicated by colored stars) of representative seafloor photographs. For each photograph, an explanation of the observed seafloor characteristics recorded by USGS and NOAA scientists is given. Note that individual photographs often show more substrate types than are reported as the primary and secondary substrate. Organisms, when present, are labeled on the photographs.

The ground-truth survey is designed to investigate areas that represent the full spectrum of highresolution multibeam bathymetry and backscatter-intensity variation. Figure 5-2 shows that, in the Offshore of Bodega Head map area, the seafloor surface is predominantly composed of rock and sand. The bathymetry and seafloor-character maps (see sheets 1,2,5 of this report) show that the offshore includes a large area of exposed granitic rock, which is continuous with outcrops onshore on Bodega Head (sheet 10), that extends from the shoreline to as far as the limit of California's State Waters. Smooth seafloor north of Bodega Head results from sediment (sand and mud) onlapping this graniticrock outcrop (see fig. 3 on sheet 8 of this report). Smooth seafloor to the south in Bodega Bay is primarily sand, and it includes a large transverse bar that formed on the more wave-protected east flank of Bodega Head. 
Substrate Distribution for Offshore of Bodega Head Map Area

Primary Substrate $=\square$ Secondary Substrate $=\square$

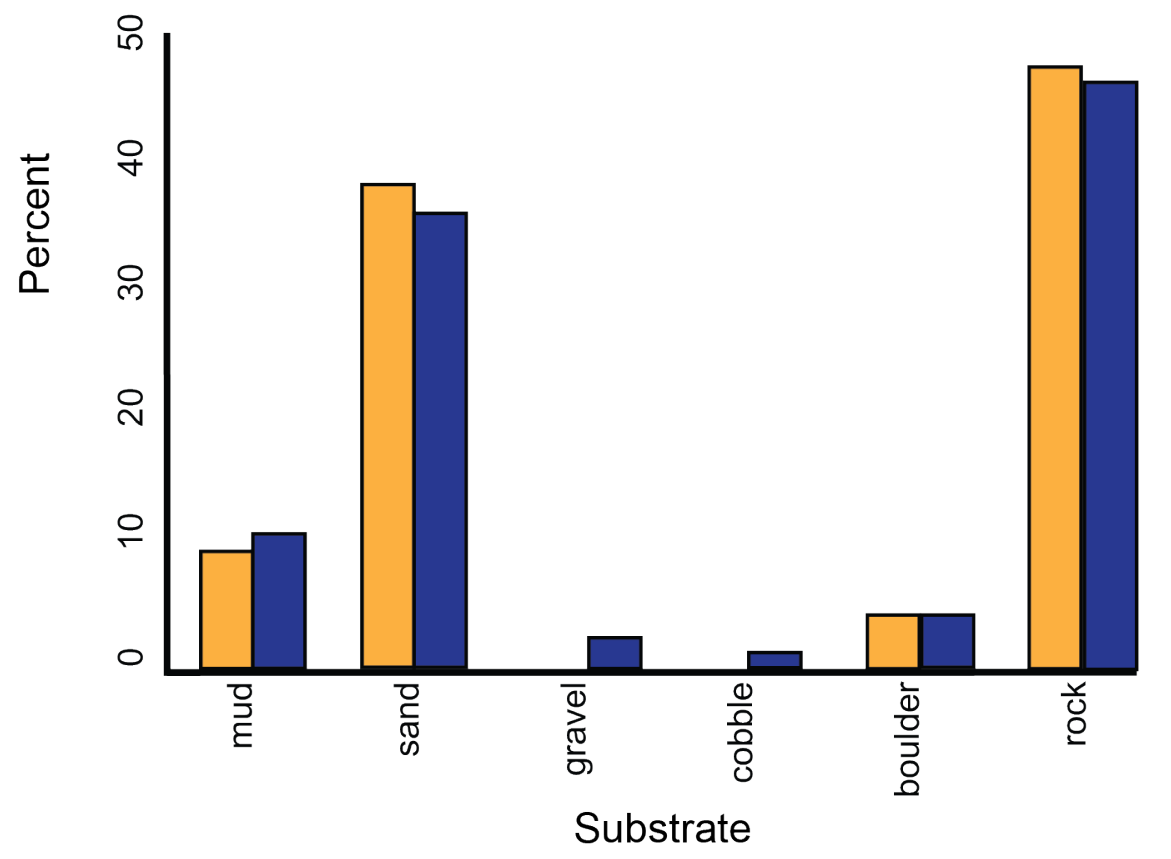

Figure 5-2. Graph showing distribution of primary and secondary substrate determined from video observations in Offshore of Bodega Head map area. 


\title{
Chapter 6. Potential Marine Benthic Habitats of the Offshore of Bodega Head Map Area (Sheet 7)
}

\author{
By H. Gary Greene, Charles A. Endris, and Bryan E. Dieter
}

The map on sheet 7 shows "potential" marine benthic habitats in the Offshore of Bodega Head map area, representing a substrate type, geomorphology, seafloor process, or any other attribute that may provide a habitat for a specific species or assemblage of organisms. This map, which is based largely on seafloor geology, also integrates information displayed on several other thematic maps of the Offshore of Bodega Head map area. High-resolution sonar bathymetry data, converted to depth grids (seafloor DEMs; sheet 1), are essential to development of the potential marine benthic habitat map, as is shadedrelief imagery (sheet 2), which allows visualization of seafloor terrain and provides a foundation for interpretation of submarine landforms.

Backscatter maps (sheet 3) also are essential for developing potential benthic habitat maps. High backscatter is further indication of "hard" bottom, consistent with interpretation as rock or coarse sediment. Low backscatter, indicative of a "soft" bottom, generally indicates a fine-sediment environment. Habitat interpretations also are informed by actual seafloor observations from ground-truth surveying (sheet 6), by seafloor-character maps that are based on video-supervised maximum-likelihood classification (sheet 5), and by seafloor-geology maps (sheet 10). The habitat interpretations on sheet 7 are further informed by the usSEABED bottom-sampling compilation of Reid and others (2006).

Broad, generally smooth areas of seafloor that lack sharp and angular edge characteristics are mapped as "sediment;" these areas may be further defined by various sedimentary features (for example, erosional scours and depressions) and (or) depositional features (for example, dunes, mounds, or sand waves). In contrast, many areas of seafloor bedrock exposures are identified by their common sharp edges and high relative relief; these may be contiguous outcrops, isolated parts of outcrop protruding through sediment cover (pinnacles or knobs), or isolated boulders. In many locations, areas within or around a rocky feature appear to be covered by a thin veneer of sediment; these areas are identified on the habitat map as "mixed" induration (that is, containing both rock and sediment). The combination of remotely observed data (for example, high-resolution bathymetry and backscatter, seismic-reflection profiles) and directly observed data (for example, camera transects, sediment samples) translates to higher confidence in the ability to interpret broad areas of the seafloor.

To avoid any possible misunderstanding of the term "habitat," the term "potential habitat" (as defined by Greene and others, 2005) is used herein to describe a set of distinct seafloor conditions that in the future may qualify as an "actual habitat." Once habitat associations of a species are determined, they can be used to create maps that depict actual habitats, which then need to be confirmed by in situ observations, video, and (or) photographic documentation.

\section{Classifying Potential Marine Benthic Habitats}

Potential marine benthic habitats in the Offshore of Bodega Head map area are mapped using the Benthic Marine Potential Habitat Classification Scheme, a mapping-attribute code developed by Greene and others $(1999,2007)$. This code, which has been used previously in other offshore California areas (see, for example, Greene and others, 2005, 2007), was developed to easily create categories of marine benthic habitats that can then be queried within a GIS or a database. The code contains several categories that can be subdivided relative to the spatial scale of the data. The following categories can be applied directly to habitat interpretations determined from remote-sensing imagery collected at a scale of tens of kilometers to one meter: Megahabitat, Seafloor Induration, Meso/Macrohabitat, Modifier, Seafloor Slope, Seafloor Complexity, and Geologic Unit. Additional categories of Macro/Microhabitat, 
Seafloor Slope, Seafloor Complexity, and Geologic Attribute can be applied to habitat interpretations determined from seafloor samples, video, still photographs, or direct observations at a scale of 10 meters to a few centimeters. These two scale-dependent groups of categories can be used together, to define a habitat across spatial scales, or separately, to compare large- and small-scale habitat types.

The four categories and their attribute codes that are used on the Offshore Bodega Head map are explained in detail below (note, however, that not all categories may be used in a particular map area, given the study objectives, data availability, or data quality); attribute codes in each category are depicted on the map by the letters and, in some cases, numbers that make up the map-unit symbols:

Megahabitat-Based on depth and general physiographic boundaries; used to distinguish features on a scale of tens of kilometers to kilometers. Depicted on map by capital letter, listed first in map-unit symbol; generalized depth ranges are given below.

$\mathrm{E}=\quad$ Estuary $(0$ to $100 \mathrm{~m})$

$\mathrm{S}=\quad$ Shelf; continental and island shelves $(0$ to $200 \mathrm{~m})$

Seafloor Induration - Refers to substrate hardness. Depicted on map by lower-case letter, listed second in map-unit symbol; may be further subdivided into distinct sediment types, depicted by lowercase letter(s) in parentheses, listed immediately after substrate hardness; multiple attributes listed in general order of relative abundance, separated by slash; queried where inferred.
$\mathrm{h}=\quad$ Hard bottom (for example, rock outcrop or sediment pavement)
$\mathrm{m}=\quad$ Mixed hard and soft bottom (for example, local sediment cover of bedrock)
$\mathrm{s}=\quad$ Soft bottom; sediment cover
$(b)=$ Boulders
(g) $=$ Gravel
$(\mathrm{s})=\quad$ Sand
$(\mathrm{m})=$ Mud, silt, and (or) clay

Meso/Macrohabitat - Related to scale of habitat; consists of seafloor features one kilometer to one meter in size. Depicted on map by lower-case letter and, in some cases, additional lower-case letter in parentheses, listed third in map-unit symbol; multiple attributes separated by slash.
$b=\quad$ Beach, relic (submerged) or shoreline
$(b) / p=$ Pinnacle indistinguishable from boulder
$\mathrm{d}=\quad$ Deformed, tilted and (or) folded bedrock; overhang
$\mathrm{e}=\quad$ Exposure; bedrock
$\mathrm{h}=\quad$ Hole; depression
$\mathrm{m}=\quad$ Mound; linear ridge
$\mathrm{p}=\quad$ Pinnacle; cone
$\mathrm{S}=\quad$ Scarp, cliff, fault, or slump scar
$\mathrm{w}=\quad$ Dynamic bedform
$y=\quad$ Delta; fan

Modifier-Describes texture, bedforms, biology, or lithology of seafloor. Depicted on map by lower-case letter, in some cases followed by additional lower-case letter(s) either after hyphen or in parentheses (or both), following an underscore; multiple attributes separated by slash.

_a = Anthropogenic (artificial reef, breakwall, shipwreck, disturbance)

$(\mathrm{a}-\mathrm{dg})=$ Dredge groove or channel

$(\mathrm{a}-\mathrm{g})=$ Groin, jetty, rip-rap

$(\mathrm{a}-\mathrm{w})=$ Wreck, ship, barge, or plane

conglomerate)

$\mathrm{C}=\quad$ Consolidated sediment (claystone, mudstone, siltstone, sandstone, breccia, or

$\begin{array}{ll}-d= & \text { Differentially eroded } \\ -f= & \text { Fracture, joint; faulted }\end{array}$ 
- $\mathrm{g}=$ Granite

- $\mathrm{h}=$ Hummocky, irregular relief

- $r=$ Ripple (amplitude, greater than $10 \mathrm{~cm}$ )

- $\mathbf{S}=\quad$ Scour (current or ice; direction noted)

$-\mathrm{u}=$ Unconsolidated sediment

\section{Examples of Attribute Coding}

To illustrate how these attribute codes can be used to describe remotely sensed data, the following examples are given:

Ss(s)_u = Soft, unconsolidated sediment (sand) on continental shelf.

$\mathrm{Es}(\mathrm{s} / \mathrm{m}) \_r / \mathrm{u}=$ Rippled, soft, unconsolidated sediment (sand and mud) in estuary.

She_g = Hard rock outcrop (granite), on continental shelf.

\section{Map Area Habitats}

Delineated in the Offshore of Bodega Head map area are 22 potential marine benthic habitat types, covering $138.88 \mathrm{~km}^{2}$ of interpreted data. These habitat types include unconsolidated continental shelf sediments ( 9 habitat types); soft, unconsolidated sediment in estuary ( 1 habitat type); mixed substrate on continental shelf ( 3 habitat types); hard substrate on continental shelf ( 5 habitat types); and anthropogenic features (4 habitat types, consisting of hard mounds, dredged channels, and groins or jetties). The predominant habitat type — soft, unconsolidated sediment_covers $100.17 \mathrm{~km}^{2}(72.1$ percent) of the offshore part of the map area. Exposed hard bedrock covers $36.15 \mathrm{~km}^{2}(26.0$ percent); sediment-covered bedrock, which is of the mixed hard-soft induration class, covers $2.45 \mathrm{~km}^{2}(1.8$ percent); and anthropogenic features cover $0.11 \mathrm{~km}^{2}(0.1$ percent $)$, on both the continental shelf and in an estuary. Rock outcrops and rubble are considered the primary habitat types for rockfish (Sebastes spp.) and lingcod (Ophiodon elongatus) (Cass and others, 1990; Love and others, 2002), both of which are recreationally and commercially important species. 


\title{
Chapter 7. Subsurface Geology and Structure of the Offshore of Bodega Head Map Area and the Salt Point to Drakes Bay Region (Sheets 8 and 9)
}

\author{
By Samuel Y. Johnson, Stephen R. Hartwell, and Janet T. Watt
}

The seismic-reflection profiles presented on sheet 8 provide a third dimension, depth, to complement the surficial seafloor-mapping data already presented (sheets 1 through 7) for the Offshore of Bodega Head map area. These data, which are collected at two resolutions, extend to varying depths in the subsurface, depending on the purpose and mode of data acquisition. The seismic-reflection profiles (sheet 8) provide information on sediment character, distribution, and thickness, as well as potential geologic hazards, including active faults, areas prone to strong ground motion, and tsunamigenic slope failures. The information on faults provides essential input to national and state earthquake-hazard maps and assessments (for example, Petersen and others, 2008).

The maps on sheet 9 show the following interpretations, which are based on the seismicreflection profiles on sheet 8: the thickness of the uppermost sediment unit; the depth to base of this uppermost unit; and both the local and regional distribution of faults and earthquake epicenters (data from U.S. Geological Survey and California Geological Survey, 2010; Northern California Earthquake Data Center, 2014).

\section{Data Acquisition}

Most profiles displayed on sheet 8 (figs. 1, 2, 3, 4, 6, 7, 8, 9, 10, 11) were collected in 2009 on U.S. Geological Survey (USGS) cruise S-8-09-NC. The single-channel seismic-reflection data were acquired using the SIG 2Mille minisparker that used a 500-J high-voltage electrical discharge fired 1 to 4 times per second, which, at normal survey speeds of 4 to 4.5 nautical miles/hour, gives a data trace every 0.5 to $2.0 \mathrm{~m}$ of lateral distance covered. The data were digitally recorded in standard SEG-Y 32bit floating-point format, using Triton Subbottom Logger (SBL) software that merges seismic-reflection data with differential GPS-navigation data. After the survey, a short-window (20 ms) automatic gain control algorithm was applied to the data, along with a 160- to 1,200-Hz bandpass filter and a heave correction that uses an automatic seafloor-detection window (averaged over $30 \mathrm{~m}$ of lateral distance covered). These data can resolve geologic features just a few meters thick, down to subbottom depths of about $400 \mathrm{~m}$.

Figure 5 on sheet 8 shows a deep-penetration, migrated, multichannel seismic-reflection profile collected in 1982 by WesternGeco on cruise W-4-82-NC. This profile and other similar data were collected in many areas offshore of California in the 1970s and 1980s when these areas were considered a frontier for oil and gas exploration. Most of these data have been publicly released and are now archived at the U.S. Geological Survey National Archive of Marine Seismic Surveys (U.S. Geological Survey, 2009). These data were acquired using a large-volume air-gun source that has a frequency range of 3 to $40 \mathrm{~Hz}$ and recorded with a multichannel hydrophone streamer about $2 \mathrm{~km}$ long. Shot spacing was about $30 \mathrm{~m}$. These data can resolve geologic features that are 20 to $30 \mathrm{~m}$ thick, down to subbottom depths of about $4 \mathrm{~km}$.

\section{Seismic-Reflection Imaging of the Continental Shelf}

Sheet 8 shows seismic-reflection profiles in the Offshore of Bodega Head map area. The map area is cut by the San Andreas Fault (see figs. 1, 2, 3, 6, 7, 8, 9, 10, 11 on sheet 8; see also, sheet 10), and the uplift of granitic rocks on the west side of this structure has created an extensive, rugged and 
rocky shelf. This rocky terrain, centered offshore of Bodega Head, extends northwestward for about 15 $\mathrm{km}$, from near the south edge of the map area (where it forms the west boundary of Bodega Bay) to the central part of the map area offshore of the mouth of Salmon Creek. This rocky seafloor reaches water depths of about 40 and $50 \mathrm{~m}$ to the south and north of Bodega Head, respectively, where it is overlain by young sediment; southwest of Bodega Head, the rocky seafloor reaches its maximum water depth of about $80 \mathrm{~m}$. Both the rocky seafloor and the smooth, sediment-covered parts of the shelf dip offshore about $0.7^{\circ}$ to $0.8^{\circ}$.

Surficial and shallow sediments were deposited in the last about 21,000 years during the sealevel rise that followed the last major lowstand associated with the Last Glacial Maximum (LGM) (Fairbanks, 1989; Fleming and others, 1998; Lambeck and Chappell, 2001; Peltier and Fairbanks, 2006). Sea level was about $125 \mathrm{~m}$ lower during the LGM, at which time the Offshore of Bodega Head map area was emergent and the shoreline was about $20 \mathrm{~km}$ west of its present-day location. The post-LGM sealevel rise was rapid (about 9 to $11 \mathrm{~m}$ per thousand years) until about 7,000 years ago, when it slowed considerably to about $1 \mathrm{~m}$ per thousand years (Peltier and Fairbanks, 2006; Stanford and others, 2011). Sea-level rise lead to a broadening of the continental shelf, the progressive eastward migration of the shoreline and wave-cut platform, and the associated transgressive erosion and deposition (see, for example, Catuneanu, 2006).

The sediments deposited during the post-LGM sea-level rise (the rapid transgression and highstand) are shaded blue in the high-resolution seismic-reflection profiles on sheet 8 (figs. 1, 2, 3, 4, 6, $7,8,9,10,11$ ), and their thickness is shown on sheet 9 (Maps B, D). The contact between underlying units and the post-LGM sediment is an abrupt transgressive surface of erosion (see, for example, Catuneanu, 2006), commonly marked by minor channeling and an upward change to lower amplitude, more diffuse reflections. These relatively low-amplitude reflections typically have low- to highfrequency, parallel to divergent geometries, and are continuous to moderately continuous (terminology from Mitchum and others, 1977). The relatively low amplitude may partly result from extensive winnowing from wave energy and currents, resulting in a uniform sediment grain size. These conditions tend to minimize the acoustic-impedance contrasts needed to produce seismic reflections that have higher amplitudes.

The smooth shelf in the northern part of the map area, between water depths of 40 and $70 \mathrm{~m}$, includes an about 3.5-km-wide field of elongate, shore-normal field of sediment lobes and chutes. Individual lobes within the field are as much as $1,000 \mathrm{~m}$ long and $150 \mathrm{~m}$ wide (see sheets $1,2,10$ ), and they have as much as $4 \mathrm{~m}$ of relief above the surrounding smooth seafloor. Seismic-reflection profile PR-147C (fig. 4 on sheet 8) shows the minor seafloor relief (vertical exaggeration, 12.5:1) of the lobes but not their internal structure. Seismic-reflection profile PR-102 (fig. 1 on sheet 8), which extends through the southeast end of the sediment-lobe field, reveals a shallow zone of disturbance at the upper end of the field that is interpreted as a slope-failure surface. This sediment-lobe field lies just $1 \mathrm{~km}$ west of the San Andreas Fault, and it is likely that strong ground motions generated by large earthquakes on this fault have triggered such slope failures, mobilizing small flows of sediment that move down the gently sloping shelf and are deposited as lobes.

Strata that underlie the post-LGM transgressive surface of erosion and overlie bedrock are represented on sheet 8 (see, for example, figs. 1 through 4) by low- to high-amplitude, high-frequency, parallel to subparallel, continuous reflections. Reflections are flat to very gently folded and typically have dips of $0^{\circ}$ to $2^{\circ}$ (note that dips may appear steeper on the profiles because of the 12.5:1 vertical exaggeration). These strata are inferred to be Pleistocene in age (marine isotope stage 3 and older; Wright, 2000; Waelbroeck and others, 2002) because they underlie post-LGM strata; in addition, their horizons can be traced continuously, along with other USGS data (from cruise S-8-09-NC), to the Quaternary section penetrated by nearby Shell Oil Company offshore well P-053-1 (Heck and others, 
1990), which lies $12 \mathrm{~km}$ southwest of the map area. Similar to the overlying post-LGM deposits, these inferred Pleistocene strata predominantly represent wave-reworked shelf sediments.

The granitic rocks of Bodega Head, well exposed onland (Blake and others, 2002), yield "reflection free" zones on seismic profiles (figs. 2, 3, 8, 9, 10, 11 on sheet 8). Nearby outcrops onshore (Clark and Brabb, 1997), and also offshore wells (Heck and others, 1990), reveal that these granitic rocks are overlain to the west and north by folded Neogene sedimentary rocks, which are imaged by folded, high-frequency seismic reflections (see southwest end of fig. 3 on sheet 8). The San Andreas Fault (figs. 1, 2, 3, 5, 6, 7, 8, 9, 10, 11 on sheet 8) juxtaposes rocks of the Jurassic and Cretaceous Franciscan Complex to the northeast with Cretaceous granitic rocks to the southwest. Rocks of the Franciscan Complex are similarly reflection free, and, thus, it is not possible to distinguish Franciscan Complex bedrock from Cretaceous granitic-rock bedrock on seismic-reflection profiles.

\section{Geologic Structure and Recent Deformation}

The Offshore of Bodega Head map area is cut by the northwest-striking San Andreas Fault, the right-lateral transform boundary between the North American and Pacific plates. From southeast to northwest, this fault runs through Bodega Bay and Bodega Harbor, crosses the Bodega Head isthmus south of the mouth of Salmon Creek, and extends offshore for about $20 \mathrm{~km}$ before passing onland just south of Fort Ross, about $10 \mathrm{~km}$ north of the map area. Geologic studies nearby along the onland section of the San Andreas Fault suggest a slip rate of 17 to $25 \mathrm{~mm} / \mathrm{yr}$ (U.S. Geological Survey and California Geological Survey, 2010).

In the offshore part of the map area, the San Andreas Fault and other faults in the Offshore of Bodega Head map area are identified on seismic-reflection profiles on the basis of the abrupt truncation or warping of reflections and (or) the juxtaposition of reflection panels that have differing seismic parameters, such as reflection presence, amplitude, frequency, geometry, continuity, and vertical sequence. Our mapping north of Bodega Head (figs. 1, 2, 3 on sheet 8) reveals a 500- to 1,100-m-wide zone characterized by two or three primary fault strands (see sheet 10). Two profiles on sheet 8 (figs. 1, 2) image an elongate, narrow, asymmetric, intra-fault zone, post-LGM sedimentary basin within the San Andreas Fault Zone.

Mapping of the San Andreas Fault Zone to the south in Bodega Bay (sheet 10) reveals a more complex zone characterized by multiple fault strands. Bathymetric data (sheets 1,2) and seismicreflection profiles (figs. 8 through 11 on sheet 8) show that Bodega Bay is flanked by rough seafloor, which consists of reflection-free rocks of the Franciscan Complex on the northeast and Cretaceous granitic rocks on the southwest. The smooth seafloor in the center of Bodega Bay is underlain by thin, post-LGM sediments, as well as an underlying unit of inferred Pleistocene age that is characterized by faulted and folded seismic reflections that reveal numerous channels and angular unconformities. The presence of this sedimentary unit between fault-bounded uplifts of much older rocks suggests that Bodega Bay originated as a pull-apart sedimentary basin (see, for example, Mann, 2007), probably formed by an eastward transfer of slip within the San Andreas Fault Zone. If so, the pervasive internal folding and faulting of the young basin fill suggests that basin subsidence has ended and the basin fill is now being deformed. The size of this intra-fault zone basin (about $9 \times 2 \mathrm{~km}$ ) is notably similar to that of the San Andreas graben (Cooper, 1973; Johnson and others, 2015), present within the San Andreas Fault Zone between Bolinas and San Francisco, about $60 \mathrm{~km}$ to the south. The San Andreas graben is at an earlier stage of development; subsidence is ongoing, and the basin fill is undeformed.

Map E on sheet 9 shows the regional pattern of major faults and earthquakes. Fault locations are simplified and compiled from interpretation of regional multichannel industry seismic-reflection data, from our mapping within California's State Waters (see sheet 10), from McCulloch (1987), and from the U.S. Geological Survey's Quaternary fault and fold database (U.S. Geological Survey and California 
Geological Survey, 2010). Earthquake epicenters are from the Northern California Earthquake Data Center (2014), which is maintained by the U.S. Geological Survey and the University of California, Berkeley, Seismological Laboratory; all events of magnitude 2.0 and greater for the time period 1967 through March 2014 are shown. The largest earthquake in the map area (M2.4, 12/21/1998) was located within the broad San Andreas Fault Zone north of Bodega Head. A notable lack of seismicity on this section of the San Andreas Fault has occurred since the devastating great 1906 California earthquake (M7.8, 4/18/1906), thought to have nucleated on the San Andreas Fault offshore of San Francisco (see, for example, Bolt, 1968; Lomax, 2005), about $70 \mathrm{~km}$ south of the map area.

\section{Thickness and Depth to Base of Uppermost Pleistocene and Holocene Deposits}

Maps on sheet 9 show the thickness and the depth to base of uppermost Pleistocene and Holocene (post-LGM) deposits, both for the Offshore of Bodega Head map area (Maps A, B) and, to establish regional context, for a larger area (about $115 \mathrm{~km}$ of coast) that extends from the Salt Point area south to the southern part of the Point Reyes peninsula (Maps C, D). To make these maps, water bottom and depth to base of the LGM horizons were mapped from seismic-reflection profiles using Seisworks software. The difference between the two horizons was exported from Seisworks for every shot point as XY coordinates (UTM zone 10) and two-way travel time (TWT). The thickness of the post-LGM unit (Maps B, D) was determined by applying a sound velocity of $1,600 \mathrm{~m} / \mathrm{sec}$ to the TWT, resulting in thicknesses as great as about $56 \mathrm{~m}$. The thickness points were interpolated to a preliminary continuous surface, overlaid with zero-thickness bedrock outcrops (see sheet 10), and contoured following the methodology of Wong and others (2012).

Several factors required manual editing of the preliminary sediment-thickness maps to make the final product. The Gualala, Point Reyes, and San Andreas Faults disrupt the sediment sequence in the region (Maps D, E on sheet 9). The thickness data points also are dense along tracklines (about $1 \mathrm{~m}$ apart) and sparse between tracklines (1 km apart), resulting in contouring artifacts. To incorporate the effect of the faults, to remove irregularities from interpolation, and to reflect other geologic information and complexity, the resulting interpolated contours were modified. Contour modifications and regridding were repeated several times to produce the final regional sediment-thickness map (Wong and others, 2012). Information for the depth to base of the post-LGM unit (Maps A, C on sheet 9) was generated by adding the thickness data to water depths determined by multibeam bathymetry (see sheet $1)$.

The thickness of the post-LGM unit in the Offshore of Bodega Head map area ranges from 0 to $56 \mathrm{~m}$ (Map B on sheet 9), and the depth to the base of this unit ranges from about 10 to $100 \mathrm{~m}$ (Map A on sheet 9). Mean sediment thickness for the map area is $9.9 \mathrm{~m}$, and the total sediment volume is $1,356 \times 10^{6} \mathrm{~m}^{3}$ (table $7-1$ ). The thickest sediment is found in two areas in the northern part of the map area, (1) within a narrow (about $300 \mathrm{~m}$ wide), elongate (about $3 \mathrm{~km}$ long) sedimentary basin that formed within the San Andreas Fault Zone (figs. 1, 2 on sheet 8), and (2) west of the San Andreas Fault, at water depths of about 40 to $60 \mathrm{~m}$, in the southern part of a midshelf mudbelt (fig. 1, Maps C, D on sheet 9). The primary source for the thick mudbelt sediment is the Russian River, which occupies a large watershed $\left(3,470 \mathrm{~km}^{2}\right)$ and has a very large sediment load (estimated 900,000 metric tons/yr; Farnsworth and Warrick, 2007). A paleochannel offshore of the much smaller Salmon Creek watershed (about 91 $\mathrm{km}^{2}$ ) also feeds the midshelf zone from the southeast (Map B on sheet 9), and Salmon Creek is considered a secondary sediment source. Farther south, much of the seafloor west of Bodega Head is characterized either by outcrops of Cretaceous granitic basement rocks (see sheet 10) or by a thin to moderately thick (as much as $23 \mathrm{~m}$ ) layer of relatively fine-grained sediment that onlaps these basement rocks from the west (figs. 3, 4 on sheet 8). 
Bodega Bay straddles the San Andreas Fault Zone, which forms an approximately 2-km-wide linear basin bounded on the east by seafloor outcrops of the Jurassic and Cretaceous Franciscan Complex and on the west by seafloor outcrops of Cretaceous granitic rocks (see sheet 10). The sediment cover between the flanking basement terranes is relatively thin $(0$ to about $10 \mathrm{~m})$ and has a complex, irregular distribution that is consistent with its location in an actively deforming fault zone. The isopach maps (Maps B, D) reveal a southwest-trending paleochannel that exits Bodega Bay in the southern part of the map area, which provided a sea-level-lowstand outlet for small, local coastal watersheds and estuaries such as Tomales Bay, Estero Americano, and Estero de San Antonio (fig. 1-2; see also, Maps A, B on sheet 9).

Five different "domains" of sediment thickness are recognized on the regional sedimentthickness map (Map D on sheet 9), each with distinctive geologic controls: (1) The Salt Point shelf domain, located in the far northwestern part of the region, has a mean sediment thickness of $11.7 \mathrm{~m}$. The thickest sediment (20 to $25 \mathrm{~m}$ ) is found where a pre-LGM, regressive, downlapping sediment wedge formed above a break in slope that is controlled by a contact between harder bedrock and softer, folded Pleistocene strata. Sediment thinning in this domain within the outer parts of California's State Waters is the result of a relative lack of sediment supply from local watersheds, as well as a more distal Russian River source. (2) The Russian River delta and mud belt domain, located offshore of the Russian River, the largest sediment source on this part of the coast, has the thickest uppermost Pleistocene and Holocene sediment in the region (mean thickness, $21.1 \mathrm{~m}$ ). The northward extension into the midshelf "mud belt" results from northward shelf-bottom currents and sediment transport (Drake and Cacchione, 1985). This domain includes a section of the San Andreas Fault Zone, which here is characterized by several releasing, right-stepping strands that bound narrow, elongate pull-apart basins; these sedimentary basins contain the greatest thickness of uppermost Pleistocene and Holocene sediment (about $56 \mathrm{~m}$ ) in the region. (3) The Bodega Head-Tomales Point shelf domain, located between Bodega Head and the Point Reyes headland, contains the least amount of sediment in the region (mean thickness, $3.4 \mathrm{~m}$ ). The lack of sediment primarily reflects decreased accommodation space and limited sediment supply. (4) The Point Reyes bar domain, located west and south of the Point Reyes headland, is a local zone of increased sediment thickness (mean thickness, $14.3 \mathrm{~m}$ ) created by bar deposition on the more protected south flank of the Point Reyes headland during rising sea level. (5) The Bolinas shelf domain, located east and southeast of the Point Reyes headland, has a thin sediment cover (mean thickness, $5.6 \mathrm{~m}$ ), which likely reflects a limited sediment "accommodation space" (Catuneanu, 2006) caused by tectonic uplift (water depths in this domain within California's State Waters are less than $45 \mathrm{~m}$ ), and high wave energy, capable of reworking and transporting shelf sediment to deeper water. 
Table 7-1. Area, sediment-thickness, and sediment-volume data for California's State Waters in Salt Point to Drakes Bay region (domains 1-5), as well as in Offshore of Bodega Head map area.

\begin{tabular}{|c|c|c|c|}
\hline \multicolumn{4}{|c|}{ Regional sediment-thickness domains in Salt Point to Drakes Bay region } \\
\hline & Area $\left(\mathrm{km}^{2}\right)$ & $\begin{array}{l}\text { Mean sediment } \\
\text { thickness }(\mathrm{m})\end{array}$ & $\begin{array}{l}\text { Sediment volume }\left(10^{6}\right. \\
\left.\mathrm{m}^{3}\right)\end{array}$ \\
\hline Entire Salt Point to Drakes Bay region & 714 & 9.5 & 6,794 \\
\hline (1) Salt Point shelf & 90 & 11.7 & 1,054 \\
\hline (2) Russian River delta and mud belt & 144 & 21.1 & 3,031 \\
\hline (3) Bodega Head-Tomales Point shelf & 275 & 3.4 & 928 \\
\hline (4) Point Reyes bar & 72 & 14.3 & 1,029 \\
\hline (5) Bolinas shelf & 133 & 5.6 & 752 \\
\hline \multicolumn{4}{|c|}{ Sediment thickness in Offshore of Bodega Head map area } \\
\hline Offshore of Bodega Head map area & 137 & 9.9 & 1,356 \\
\hline Russian River delta and mud belt & 26 & 27.3 & 739 \\
\hline Bodega Head-Tomales Point shelf & 110 & 5.6 & 618 \\
\hline
\end{tabular}




\title{
Chapter 8. Geologic and Geomorphic Map of the Offshore of Bodega Head Map Area (Sheet 10)
}

\author{
By Samuel Y. Johnson, Michael W. Manson, and Stephen R. Hartwell
}

\section{Geologic and Geomorphic Summary}

Marine geology and geomorphology were mapped in the Offshore of Bodega Head map area from approximate Mean High Water (MHW) to the 3-nautical-mile limit of California's State Waters. MHW is defined at an elevation of $1.46 \mathrm{~m}$ above the North American Vertical Datum of 1988 (NAVD 88) (Weber and others, 2005). Offshore geologic units were delineated on the basis of integrated analyses of adjacent onshore geology with multibeam bathymetry and backscatter imagery (sheets 1, 2, 3), seafloor-sediment and rock samples (Reid and others, 2006), digital camera and video imagery (sheet 6 ), and high-resolution seismic-reflection profiles (sheet 8). Aerial photographs taken in multiple years were used to map the nearshore area ( 0 to $10 \mathrm{~m}$ water depth) and to link the offshore and onshore geology. The relative proportions of all offshore map units are shown in table 8-1.

Onshore bedrock mapping is compiled from Blake and others (2002) and Wagner and Gutierrez (2010; unpub. data). Onshore Quaternary mapping is compiled from Witter and others (2006) and Wagner and Gutierrez (2010), with some additional mapping by M.W. Manson (this report); in addition, some units are modified by M.W. Manson on the basis of analysis of 2003 and 2012 lidar imagery. Traces of the San Andreas Fault are compiled from Brown and Wolfe (1972), California Geological Survey (1974a,b,c), and previously unpublished mapping by M.W. Manson.

The geology and geomorphology of the offshore part of the Offshore of Bodega Head map area are the result of the interplay between tectonics, sea-level rise, local sedimentary processes, and oceanography. The map area is cut by the northwest-striking San Andreas Fault, the right-lateral transform boundary between the North American and Pacific plates. From southeast to northwest, this fault runs through Bodega Bay and Bodega Harbor, crosses the Bodega Head isthmus south of the mouth of Salmon Creek, and extends offshore for about $20 \mathrm{~km}$ before passing onland just south of Fort Ross, about $10 \mathrm{~km}$ north of the map area. Onshore investigations to the north near Fort Ross (fig. 1-1) indicate that the San Andreas Fault in this area has a slip rate of about 17 to $25 \mathrm{~mm} / \mathrm{yr}$ (U.S. Geological Survey and California Geological Survey, 2010). Emergent marine terraces near Bodega Bay record rates of uplift associated with the fault system of about $0.1 \mathrm{~mm} / \mathrm{yr}$ (Landis and others, 2004). The destructive great 1906 California earthquake (M7.8, 4/18/1906) is thought to have nucleated on the San Andreas Fault offshore of San Francisco (see, for example, Bolt, 1968; Lomax, 2005), about 70 kilometers south of the map area. Fault rupture in the 1906 earthquake extended about $300 \mathrm{~km}$ northward from the epicenter through the Offshore of Bodega Head map area (Lawson, 1908; Brown and Wolfe, 1972) to the south flank of Cape Mendocino.

The San Andreas Fault Zone in the Offshore of Bodega Head map area is complex, characterized by multiple, parallel to subparallel, offshore strands in Bodega Bay and northwest of Bodega Head.

Most notably, the offshore mapping suggests the presence of an important strand about $800 \mathrm{~m}$ southwest of the only reported 1906 rupture in the map area, a 200-m-long "well-defined fissure" (Lawson, 1908; Brown and Wolfe, 1972). Onland, this inferred southwest strand cuts through a large (about $4 \mathrm{~km}^{2}$ ) field of poorly consolidated sand dunes, within which such a fissure would not likely develop.

The San Andreas Fault Zone (figs. 1, 2, 3, 5, 6, 7, 8, 9, 10, 11 on sheet 8) juxtaposes rocks of the Jurassic and Cretaceous Franciscan Complex on the northeast with Cretaceous granitic rocks on the southwest. Uplift of the granitic rocks (units $\mathrm{Kg}$ ) on the southwest has created an extensive, rugged and rocky seafloor, centered offshore of Bodega Head, that extends northwestward for about $15 \mathrm{~km}$, from the west flank of Bodega Bay to the shelf offshore of the mouth of Salmon Creek. This rocky seafloor 
reaches water depths of about 40 and $50 \mathrm{~m}$ to the south and north of Bodega Head, respectively; west of Bodega Head, the rocky seafloor reaches water depths of $80 \mathrm{~m}$. Northeast of the San Andreas Fault, offshore rocky outcrops of the Franciscan Complex (units Kfs, gs, fsr) are found only in the nearshore (water depths of less than $15 \mathrm{~m}$ ).

Sediment-covered areas of the offshore part of the map area are found in gently sloping (less than about $1^{\circ}$ ) nearshore, inner shelf, and midshelf environments. Sediment supply to the shelf north and west of Bodega Head is predominantly from coastal watersheds, which include the Russian River (4.5 $\mathrm{km}$ north of the map area) and Salmon Creek. Sediment supply to Bodega Bay and the shelf in the southern part of the map area is from small coastal watersheds and estuaries such as Estero Americano and Estero de San Antonio, and possibly also from sediment flux out of the mouth of Tomales Bay, 2 $\mathrm{km}$ south of the map area. Shelf morphology and evolution largely reflects eustacy; sea level has risen about 125 to $130 \mathrm{~m}$ over about the last 21,000 years (see, for example, Lambeck and Chappell, 2001; Stanford and others, 2011), leading to a broadening of the continental shelf, the progressive eastward migration of the shoreline and wave-cut platform, and associated transgressive erosion and deposition.

Given the present exposure to high wave energy, modern nearshore to inner shelf sediments are mostly sand (unit Qms) and (or) a mix of sand, gravel, and cobbles (units Qmsc and Qmsd). Coarser grained sands and gravels (units Qmsc and Qmsd) are recognized primarily on the basis of bathymetry and high backscatter (sheets 1, 2, 3). Unit Qmsc is mapped in two areas, (1) as a linear nearshore bar (water depths of less than $10 \mathrm{~m}$ ) offshore of Salmon Creek (the eastern contact of this unit is queried because of the lack of data in the surf zone), and (2) as an east-west-trending bar at the north end of Bodega Bay.

Unit Qmsd typically is mapped as erosional lags in scour depressions (see, for example, Cacchione and others, 1984) that are bounded by relatively sharp or, less commonly, diffuse contacts with the horizontal sand sheets of unit Qms. These depressions typically are a few tens of centimeters deep and range in area from a few tens of square meters to more than one square kilometer. Such scour depressions are common along this stretch of the California coast (see, for example, Cacchione and others, 1984; Hallenbeck and others, 2012; Davis and others, 2013) where offshore sandy sediment can be relatively thin (and, thus, is unable to fill the depressions) owing to lack of sediment supply from rivers and also to significant erosion and offshore transport of sediment during large northwest winter swells. Such features have been referred to as "rippled scour depressions" (see, for example, Cacchione and others, 1984) or "sorted bedforms" (see, for example, Murray and Thieler, 2004; Goff and others, 2005; Trembanis and Hume, 2011). Although the general areas in which both unit Qmsd scour depressions and surrounding Qms sand sheets are found are not likely to change substantially, the boundaries of the unit(s) likely are ephemeral, changing seasonally and during significant storm events.

Unit Qmsf, which lies offshore of unit Qms, consists primarily of mud and muddy sand, and it commonly is extensively bioturbated. The transition from sand-dominated marine sediment (unit Qms) to mud-dominated marine sediment (Qmsf) is at water depths of about 45 to $50 \mathrm{~m}$, except for the area offshore of Bodega Head where bedrock outcrops that extend to depths of $80 \mathrm{~m}$ at the limit of California's State Waters have little or no sediment cover.

The smooth seafloor in the northern part of the map area, between water depths of 40 and $70 \mathrm{~m}$, includes an about 3.5-km-wide field of elongate, shore-normal sediment lobes (unit Qmsl). Individual lobes within the field, which are as much as $1,000 \mathrm{~m}$ long and $150 \mathrm{~m}$ wide, have as much as $4 \mathrm{~m}$ of relief above the surrounding smooth seafloor, and they commonly are transitional to upslope chutes. This sediment-lobe field lies just $1 \mathrm{~km}$ west of the San Andreas Fault, and we infer that strong ground motions generated by large earthquakes on this structure triggered slope failures, mobilizing sediment flows that moved down the gently sloping shelf and were deposited as lobes. Unit Qmsl also is present as a 250-m-wide field that consists of four discrete lobes and paired arcuate, low-relief scours, mapped on the south flank of the east-west-trending bar (unit Qmsc) in northern Bodega Bay. 
Table 8-1. Areas and relative proportions of offshore geologic map units in Offshore of Bodega Head map area.

\begin{tabular}{|c|c|c|c|}
\hline Map Unit & Area $\left(m^{2}\right)$ & Area $\left(\mathrm{km}^{2}\right)$ & Percent of total area \\
\hline Qms & $50,672,786$ & 50.7 & 34.8 \\
\hline Qmsc & $1,558,438$ & 1.6 & 1.1 \\
\hline Qmsf & $43,185,665$ & 43.2 & 29.7 \\
\hline Total, sedimentary units & $103,638,001$ & 103.6 & 71.2 \\
\hline \multicolumn{4}{|c|}{ Marine bedrock and (or) shallow bedrock units } \\
\hline $\mathrm{Kg}$ & $37,766,238$ & 37.8 & 25.9 \\
\hline Total, bedrock units & $41,928,209$ & 41.9 & 28.8 \\
\hline Total, Offshore of Bodega Head map area & $145,566,210$ & 145.6 & 100.0 \\
\hline
\end{tabular}




\section{DESCRIPTION OF MAP UNITS}

OFFSHORE GEOLOGIC AND GEOMORPHIC UNITS

Qms Marine nearshore and shelf deposits (late Holocene)_Predominantly sand; ripple marks common; found on gently seaward-dipping (less than about $1^{\circ}$ ) surface and surrounding bedrock outcrops; extends from shoreline to water depths of about 45 to $60 \mathrm{~m}$

Qmsc Coarse-grained marine nearshore and shelf deposits (late Holocene) - Predominantly coarse sand, gravel, and cobbles; found as elongate nearshore bar (water depths of less than $10 \mathrm{~m}$ ) offshore of Salmon Creek (inner boundary queried owing to lack of data); also found as elongate east-west-trending bar in northern Bodega Bay (water depths of 10 to $20 \mathrm{~m}$ ) and along boundaries of bedrock outcrops. Recognized primarily on basis of high backscatter and flat relief

Qmsf Fine-grained marine shelf deposits (late Holocene)—Predominantly mud, very fine sand, and silt; commonly bioturbated; found on gently seaward-dipping (less than $1^{\circ}$ ) surface, at depths greater than about 45 to $60 \mathrm{~m}$

Qmsd Marine shelf scour depressions (late Holocene)-Inferred to be coarse sand and gravel; found adjacent to bedrock outcrops and in northern Bodega Bay, as single depressions or in groups of depressions interspersed with elevated shelf sediments (unit Qms). Depressions have straight to irregular margins and diffuse to sharp boundaries, and they typically are 15 to $50 \mathrm{~cm}$ deep. In map area, both backscatter data and direct camera observations show small intensity contrasts, suggesting that depressions are filled with sediment that is coarser than intervening elevated sandy shelf deposits. General area in which unit is found is not likely to change substantially, but boundaries of unit(s) and locations of individual depressions (and intervening flat sheets) likely are ephemeral, changing during significant storm events

Qmsl Marine sediment lobes (late Holocene) -Mapped as (1) about 3-km-wide field of elongate, shore-normal pairs of sediment lobes and chutes, between water depths of 40 and 70 $\mathrm{m}$ in northernmost part of map area. Individual lobes within field are as much as 650 $\mathrm{m}$ long and $200 \mathrm{~m}$ wide, and they have as much as $4 \mathrm{~m}$ of relief above surrounding smooth seafloor, and (2) about 250-m-wide field of four discrete lobes and paired arcuate, low-relief scours on south flank of east-west-trending bar in northern Bodega Bay. Unit reveals failure of gentle slopes, possibly related to strong ground motion associated with earthquakes on adjacent San Andreas Fault

Kg Granitic rocks of Bodega Head (Late Cretaceous)-Seafloor outcrops of the granitic rocks of Bodega Head (mapped onland by Blake and others, 2002); mapped on basis of high backscatter and rough, massive, and fractured seafloor texture

Franciscan Complex (Cretaceous and Jurassic)

Kfs Sandstone in Central Belt (Cretaceous) - Massive to distinctly bedded feldspathic and feldspathic-lithic wacke

fsr Mélange in Central Belt (Cretaceous and (or) Jurassic)-Matrix of sheared argillite, graywacke, and minor green tuff that encloses blocks and lenses of graywacke, chert, metachert, greenstone, serpentinite, silica-carbonate rock, blueschist (metasediment and metabasalt), eclogite, amphibolite, limestone, and quartz-mica schist (Blake and others, 2002)

Greenstone blocks within mélange (Cretaceous and (or) Jurassic) — Includes massive and pillowed greenstone and basalt 


\section{ONSHORE GEOLOGIC AND GEOMORPHIC UNITS}

[Units compiled from Blake and others (2002), Witter and others (2006), and Wagner and Gutierrez (2010; unpub. data); unit ages, which are from these sources, reflect local stratigraphic relations; some units modified by M.W. Manson on basis of interpretation of 2003 and 2012 lidar imagery]
af
Artificial fill (late Holocene)-Material deposited by humans
afem
Artificial fill over estuarine mud (late Holocene)-Material deposited by humans over estuarine sediments constructed for purpose of containing floodwater or tidal waters
acf Artificial-channel fill (late Holocene) - Mapped in historically active stream channel, where streamflow has been rerouted either to pipe beneath or within fill or to pipe or channel in another location
alf Artificial-levee fill (late Holocene) — Levees bordering rivers, streams, sloughs, and islands;
adf Artificial-dam fill (late Holocene) - Earth- or rock-fill dams, embankments, and levees; constructed to impound land-locked water bodies
Qsc Stream-channel deposits (late Holocene)-Fluvial deposits within active, natural stream channels
Qbs
Qt Stream-terrace deposits (late Holocene)-Point-bar and overbank deposits elevated above modern stream channel; judged to be latest Holocene age $(<1,000$ years) on basis of records of historical inundation and (or) identification of youthful meander scars and braid bars on aerial photographs or lidar imagery

Qf Alluvial fan deposits (late Holocene) - Sediment deposited by streams emanating from canyons onto alluvial valley floors or alluvial plains; judged to be latest Holocene age $(<1,000$ years) on basis of records of historical inundation or presence of youthful braid bars and distributary channels on aerial photographs or lidar imagery

Qot Stream-terrace deposits (Holocene) - Point-bar and overbank deposits elevated above modern stream channel; older than unit Qt

Qds Dune sand (Holocene) - Active and recently stabilized dunes in coastal environments

Qe

Qed Estuarine-delta deposits (Holocene) - Heterogeneous mixture of coarse and fine estuarine sediment; deposited in deltas at mouths of tidally influenced coastal watersheds, such as Estero Americano and Estero de San Antonio, where fresh water mixes with seawater

Qof2 Alluvial fan deposits, undivided (Holocene) - Sediment deposited by streams emanating from canyons onto alluvial valley floors or alluvial plains; may include debris-flow, hyperconcentrated-mudflow, and braided-stream deposits

Qa Alluvial deposits, undivided (Holocene) - Alluvium deposited in fan, terrace, or basin environments

Qof1 Alluvial fan deposits, undivided (Holocene and late Pleistocene) - Mapped in small valleys where separate fan, basin, and terrace units could not be delineated at map scale and also where deposits might be of either late Pleistocene or Holocene age

Qls Landslide deposits (Holocene and Pleistocene) - Weathered rocks and soil; ranges from deep-seated landslides to active colluvium. Internal contacts differentiate individual landslide bodies 
Qmt Marine-terrace deposits (late Pleistocene)—Sand, gravel, and cobbles; deposited on marine-abrasion platforms and later uplifted to present-day elevations along coast

Twg Wilson Grove Formation (Pliocene and late Miocene)-Marine sandstone and conglomerate

$\mathrm{Kg}$ Granitic rocks of Bodega Head (Late Cretaceous)-Tonalite, granodiorite, and porphyritic granodiorite

KJgvc Great Valley sequence conglomerate of Healdsburg terrane (Late Cretaceous to Late Jurassic) - Pebble to boulder conglomerate

Franciscan Complex (Cretaceous and Jurassic)

Kfs Sandstone of Central Belt (Cretaceous)-Massive to distinctly bedded feldspathic and feldspathic-lithic wacke

KJfss Sandstone and shale of Central Belt (Cretaceous and (or) Jurassic)—Massive to distinctly bedded, lithic wacke, siltstone, shale, and slate, grading into mélange

fsr

ch

gs

sS

$\mathrm{sp}$

Mélange of Central Belt (Cretaceous and (or) Jurassic) -Matrix of sheared argillite, graywacke, and minor green tuff that encloses blocks and lenses of graywacke, chert, metachert, greenstone, serpentinite, silica-carbonate rock, blueschist (metasediment and metabasalt), eclogite, amphibolite, limestone, and quartz-mica schist (Blake and others, 2002)

Chert and metachert blocks within mélange (Cretaceous and (or) Jurassic) Includes massive and thinly bedded red, green, and white chert and metachert Greenstone blocks within mélange (Cretaceous and (or) Jurassic) — Includes massive and pillowed greenstone and basalt

Sandstone and shale blocks within mélange (Cretaceous and (or) Jurassic)

Ultramafic rocks of Coast Range ophiolite (Late and Middle Jurassic) — Partly to completely serpentinized peridotite 


\section{Acknowledgments}

This publication was funded by the California Ocean Protection Council and the U.S. Geological Survey (USGS) Coastal and Marine Geology Program. We thank the officers, crew, and scientific parties of the ships - R/V VenTresca, California State University, Monterey Bay, Seafloor Mapping Lab; and F/V Quicksilver, Fugro Pelagos - for their skill and professionalism in collecting the data presented in this report. We thank Douglas George, Stephen Watt, and Scott Starratt (all USGS) for the critical reviews that significantly improved this report. We are very grateful to USGS editor Taryn Lindquist for helping us develop the templates and formats for this series of publications, and for invaluable editorial review and suggestions. 


\section{References Cited}

Anderson, T.J., Cochrane, G.R., Roberts, D.A., Chezar, H., and Hatcher, G., 2007, A rapid method to characterize seabed habitats and associated macro-organisms, in Todd, B.J., and Greene, H.G., eds., Mapping the seafloor for habitat characterization: Geological Association of Canada Special Paper 47, p. 71-79.

Blake, M.C., Jr., Graymer, R.W., and Stamski, R.E., 2002, Geologic map and map database of western Sonoma, northernmost Marin, and southernmost Mendocino counties, California: U.S. Geological Survey Miscellaneous Field Studies Map 2402, scale 1:100,000, available at http://pubs.usgs.gov/ $\mathrm{mf} / 2002 / 2402 /$.

Bolt, B.A., 1968, The focus of the 1906 California earthquake: Bulletin of the Seismological Society of America, v. 58, p. 457-471.

Brown, R.D., Jr., and Wolfe, E.W., 1972, Map showing recently active breaks along the San Andreas Fault between Point Delgada and Bolinas Bay, California: U.S. Geological Survey Miscellaneous Investigations Map I-692, scale 1:24,000.

Cacchione, D.A., Drake, D.E., Grant, W.D., and Tate, G.B., 1984, Rippled scour depressions of the inner continental shelf off central California: Journal of Sedimentary Petrology, v. 54, p. 1,280-1,291.

California Department of Fish and Wildlife, 2008, California Marine Life Protection Act master plan for marine protected areas-Revised draft: California Department of Fish and Wildlife [formerly California Department of Fish and Game], available at http://www.dfg.ca.gov/mlpa/masterplan.asp.

California Department of Fish and Wildlife, 2012, Guide to the North-Central California Marine Protected Areas, Alder Creek to Pigeon Point: California Department of Fish and Wildlife [formerly California Department of Fish and Game], 66 p., available at http://www.dfg.ca.gov/marine/mpa/.

California Geological Survey, 1974a, Alquist-Priolo earthquake fault zone map of Bodega Head quadrangle: California Geological Survey, State of California Special Studies Zone Map, scale 1:24,000, available at http://www.quake.ca.gov/gmaps/WH/regulatorymaps.htm.

California Geological Survey, 1974b, Alquist-Priolo earthquake fault zone map of Duncans Mills quadrangle: California Geological Survey, State of California Special Studies Zone Map, scale 1:24,000, available at http://www.quake.ca.gov/gmaps/WH/regulatorymaps.htm.

California Geological Survey, 1974c, Alquist-Priolo earthquake fault zone map of Valley Ford quadrangle: California Geological Survey, State of California Special Studies Zone Map, scale 1:24,000, available at http://www.quake.ca.gov/gmaps/WH/regulatorymaps.htm.

Cass, A.J., Beamish, R.J., and McFarlane, G.A., 1990, Lingcod (Ophiodon elongatus): Canadian Journal of Fisheries and Aquatic Sciences, Special Publication 109, 40 p.

Catuneanu, O., 2006, Principles of sequence stratigraphy: Amsterdam, Elsevier, 375 p.

Clark, J.C., and Brabb, E.E., 1997, Geology of Point Reyes National Seashore and vicinity, CaliforniaA digital database: U.S. Geological Survey Open-File Report 97-456, scale 1:48,000, available at http://pubs.usgs.gov/of/1997/of97-456/.

Cochrane, G.R., 2008, Video-supervised classification of sonar data for mapping seafloor habitat, in Reynolds, J.R., and Greene, H.G., eds., Marine habitat mapping technology for Alaska: Fairbanks, University of Alaska, Alaska Sea Grant College Program, p. 185-194, available at http://doc.nprb.org/ web/research/research\%20pubs/615_habitat_mapping_workshop/Individual\%20Chapters\%20HighRes/Ch13\%20Cochrane.pdf.

Cochrane, G.R., Conrad, J.E., Reid, J.A., Fangman, S., and Golden, N., 2005, Nearshore benthic habitat GIS for the Channel Islands National Marine Sanctuary and southern California state fisheries reserves, vol. II: U.S. Geological Survey Open-File Report 2005-1170, available at http://pubs.usgs.gov/of/2005/1170/. 
Cochrane, G.R., and Lafferty, K.D., 2002, Use of acoustic classification of sidescan sonar data for mapping benthic habitat in the northern Channel Islands, California: Continental Shelf Research, v. 22, p. 683-690.

Cochrane, G.R., Nasby, N.M., Reid, J.A., Waltenberger, B., and Lee, K.M., 2003, Nearshore benthic habitat GIS for the Channel Islands National Marine Sanctuary and southern California state fisheries reserves vol. 1: U.S. Geological Survey Open-File Report 03-85, available at http://pubs.usgs.gov/of/ 2003/0085/.

Cooper, A.K., 1973, Structure of the continental shelf west of San Francisco, California: U.S. Geological Survey Open-File Report 73-48, 65 p.

Davis, A.C.D., Kvitek, R.G., Mueller, C.B.A., Young, M.A., Storlazzi, C.D., and Phillips, E.L., 2013, Distribution and abundance of rippled scour depressions along the California coast: Continental Shelf Research, v. 69, p. 88-100, doi:10.1016/j.csr.2013.09.010.

Demirpolat, S., 1991, Surface and near-surface sediments from the continental shelf of the Russian River, northern California: Marine Geology, v. 99, p.163-173.

Drake, D.E., and Cacchione, D.A., 1985, Seasonal variation in sediment transport on the Russian River shelf, California: Continental Shelf Research, v. 4, p. 495-514, doi:10.1016/0278-4343(85)90007-X.

Fairbanks, R.G., 1989, A 17,000-year glacio-eustatic sea level record-Influence of glacial melting rates on the Younger Dryas event and deep-ocean circulation: Science, v. 342, p. 637-642.

Farnsworth, K.L., and Warrick, J.A., 2007, Sources, dispersal, and fate of fine sediment supplied to coastal California: U.S. Geological Survey Scientific Investigations Report 2007-5254, 77 p., available at http://pubs.usgs.gov/sir/2007/5254/.

Fleming, K., Johnston, P., Zwartz, D., Yokoyama, Y., Lambeck, K., and Chappell, J., 1998, Refining the eustatic sea-level curve since the Last Glacial Maximum using far- and intermediate-field sites: Earth and Planetary Science Letters, v. 163, p. 327-342, doi:10.1016/S0012-821X(98)00198-8.

Goff, J.A., Mayer, L.A., Traykovski, P., Buynevich, I., Wilkens, R., Raymond, R., Glang, G., Evans, R.L., Olson, H., and Jenkins, C., 2005, Detailed investigations of sorted bedforms, or "rippled scour depressions," within the Martha's Vineyard Coastal Observatory, Massachusetts: Continental Shelf Research, v. 25, p. 461-484, doi:10.1016/j.csr.2004.09.019.

Greene, H.G., Bizzarro, J.J., O’Connell, V.M., and Brylinsky, C.K., 2007, Construction of digital potential marine benthic habitat maps using a coded classification scheme and its application, in Todd, B.J., and Greene, H.G., eds., Mapping the seafloor for habitat characterization: Geological Association of Canada Special Paper 47, p. 141-155.

Greene, H.G., Bizzarro, J.J., Tilden, J.E., Lopez, H.L., and Erdey, M.D., 2005, The benefits and pitfalls of geographic information systems in marine benthic habitat mapping, in Wright, D.J., and Scholz, A.J., eds., Place matters: Portland, Oregon State University Press, p. 34-46.

Greene, H.G., Yoklavich, M.M., Starr, R.M., O’Connell, V.M., Wakefield, W.W., Sullivan, D.E., McRea, J.E., and Cailliet, G.M., 1999, A classification scheme for deep seafloor habitats:

Oceanologica Acta, v. 22, p. 663-678.

Griggs, G., Patsch, K., and Savoy, L., 2005, Living with the changing California coast: Berkeley, University of California Press, $540 \mathrm{p}$.

Habel, J.S., and Armstrong, G.A., 1978, Assessment and atlas of shoreline erosion along the California coast: Sacramento, State of California, Department of Navigation and Ocean Development, $277 \mathrm{p}$. Hallenbeck, T.R., Kvitek, R.G., and Lindholm, J., 2012, Rippled scour depressions add ecologically significant heterogeneity to soft-bottom habitats on the continental shelf: Marine Ecology Progress Series, v. 468, p. 119-133, doi:10.3354/meps09948.

Hapke, C.J., and Reid, D.R., 2007, National assessment of shoreline change part 4-Historical coastal cliff retreat along the California Coast: U.S. Geological Survey Open-File Report 2007-1133, 51 p., available at http://pubs.usgs.gov/of/2007/1133/. 
Hapke, C.J., Reid, D., Richmond, B.B., Ruggiero, P., and List, J., 2006, National assessment of shoreline change part 3-Historical shoreline change and associated coastal land loss along sandy shorelines of the California coast: U.S. Geological Survey Open-File Report 2006-1219, 72 p., available at http://pubs.usgs.gov/of/2006/1219/.

Heck, R.G., Edwards, E.B., Kronen, J.D., Jr., and Willingham, C.R., 1990, Petroleum potential of the offshore outer Santa Cruz and Bodega basins, California, in Garrison, R.E., Greene, H.G., Hicks, K.R., Weber, G.E., and Wright, T.L., eds., Geology and tectonics of the central California coastal region, San Francisco to Monterey: American Association of Petroleum Geologists, Pacific Section, Bulletin GB67, p. 143-164.

Hickey, B.M., 1979, The California current system-Hypotheses and facts: Progress in Oceanography, v. 8, p. 191-279.

Johnson, S.Y., Hartwell, S.R., Sliter, R.W., Watt, J.T., Phillips, E.L., Ross, S.L., and Chin, J.L., 2015, Local (Offshore of San Francisco map area) and regional (offshore from Bolinas to Pescadero) shallow-subsurface geology and structure, California, sheet 9 in Cochrane, G.R., Johnson, S.Y., Dartnell, P., Greene, H.G., Erdey, M.D., Golden, N.E., Hartwell, S.R., Endris, C.A., Manson, M.W., Sliter, R.W., Kvitek, R.G., Watt, J.T., Ross, S.L., and Bruns, T.R. (G.R. Cochrane and S.A. Cochran, eds.), California State Waters Map Series_-Offshore of San Francisco, California: U.S. Geological Survey Open-File Report 2015-1068, pamphlet 39 p., 10 sheets, scale 1:24,000, available at http://dx.doi.org/10.3133/ofr20151068.

Kvitek, R., Bretz, C., Cochrane, G., and Greene, H.G., 2006, Final report, Statewide Marine Mapping Planning Workshop, December 12-13, 2005, Seaside, Calif.: California State University, Monterey Bay, 108 p., available at http://euclase.csumb.edu/DATA_DOWNLOAD/StrategicMapgWrkshp05/ MappingWorkshop12_12-13/Final_Report/CA\%20Habitat\%20Mapping\%20Rpt.pdf.

Kvitek, R.G., Phillips, E.L., and Dartnell, P., 2012, Colored shaded-relief bathymetry, Hueneme Canyon and vicinity, California, sheet 1 in Johnson, S.Y., Dartnell, P., Cochrane, G.R., Golden, N.E., Phillips, E.L., Ritchie, A.C., Kvitek, R.G., Greene, H.G., Krigsman, L.M., Endris, C.A., Clahan, K.B., Sliter, R.W., Wong, F.L., Yoklavich, M.M., and Normark, W.R. (S.Y. Johnson, ed.), California State Waters Map Series-Hueneme Canyon and vicinity, California: U.S. Geological Survey Scientific Investigations Map 3225, pamphlet 41 p., 12 sheets, available at http://pubs.usgs.gov/sim/3225/.

Lambeck, K., and Chappell, J., 2001, Sea level change through the last glacial cycle: Science, v. 292, p. 679-686, doi:10.1126/science.1059549.

Landis, P.S., Gardner, T.W., and Merritts, D.J., 2004, Deformation of marine terraces along the western edge of the North American Plate, Bodega Bay to the Russian River, CA: Geological Society of America Abstracts with Programs, South-Central Section, Paper 6-3.

Lawson, A.C., ed., 1908, The California earthquake of April 18, 1906, Report of the State Earthquake Investigation Commission: Carnegie Institution of Washington Publication 87, v. 1, 1,451 p. and atlas. Lomax, A., 2005, A reanalysis of the hypocentral location and related observations for the Great 1906 California earthquake: Bulletin of the Seismological Society of America, v. 95, p. 861-877, doi:10.1785/0120040141.

Love, M.S., Yoklavich, M., Thorsteinson, L., and Butler, J., 2002, The rockfishes of the northeast Pacific: Berkeley, University of California Press, 405 p., doi:10.5860/CHOICE.40-3403.

Madden, C.J., Goodin, K.L., Allee, R., Finkbeiner, M., and Bamford, D.E., 2008, Draft Coastal and Marine Ecological Classification Standard: National Oceanic and Atmospheric Administration (NOAA) and NatureServe, v. III, 77 p.

Mann, P., 2007, Global catalogue, classification, and tectonic origin of restraining and releasing bends on active and ancient strike-slip fault systems, in Cunningham, W.D., and Mann, P., eds., Tectonics of strike-slip restraining and releasing bends: Geological Society of London Special Publication 290, p. 13-142. 
McCulloch, D.S., 1987, Regional geology and hydrocarbon potential of offshore Central California, in Scholl, D.W., Grantz, A., and Vedder, J.G., eds., Geology and resource potential of the continental margin of western North America and adjacent ocean basins - Beaufort Sea to Baja California: Circum-Pacific Council for Energy and Mineral Resources, Earth Science Series, v. 6, p. 353-401. Mitchum, R.M., Jr., Vail, P.R., and Sangree, J.B., 1977, Seismic stratigraphy and global changes of sea level, part 6-Stratigraphic interpretation of seismic reflection patterns in depositional sequences, in Payton, C.E., ed., Seismic stratigraphy_Applications to hydrocarbon exploration: Tulsa, Okla., American Association of Petroleum Geologists, p. 117-133.

Murray, B., and Thieler, E.R., 2004, A new hypothesis and exploratory model for the formation of largescale inner-shelf sediment sorting and "rippled scour depressions": Continental Shelf Research, v. 24, no. 3, p. 295-315, doi:10.1016/j.csr.2003.11.001.

Northern California Earthquake Data Center, 2014, Northern California earthquake catalog: Northern California Earthquake Data Center database, accessed April 5, 2014, at http://www.ncedc.org/ncsn/. Peltier, W.R., and Fairbanks, R.G., 2006, Global glacial ice volume and Last Glacial Maximum duration from an extended Barbados sea level record: Quaternary Science Reviews, v. 25, p. 3,322-3,337, doi:10.1016/j.quascirev.2006.04.010.

Petersen, M.D., Frankel, A.D., Harmsen, S.C., Mueller, C.S., Haller, K.M., Wheeler, R.L., Wesson, R.L., Zeng, Y., Boyd, O.S., Perkins, D.M., Luco, N., Field, E.H., Wills, C.J., and Rukstales, K.S., 2008, Documentation for the 2008 update of the United States National Seismic Hazard Maps: U.S. Geological Survey Open-File Report 2008-1128, 61 p., available at http://pubs.usgs.gov/of/2008/ $1128 /$.

Phillips, E.L., Storlazzi, C.D., Dartnell, P. and Edwards, B.D., 2007, Exploring rippled scour depressions offshore Huntington Beach, California: Coastal Sediments 2007, v. 3, p. 1,851-1,864.

Reid, J.A., Reid, J.M., Jenkins, C.J., Zimmerman, M., Williams, S.J., and Field, M.E., 2006, usSEABED -Pacific Coast (California, Oregon, Washington) offshore surficial-sediment data release: U.S. Geological Survey Data Series 182, available at http://pubs.usgs.gov/ds/2006/182/.

Stanford, J.D., Hemingway, R., Rohling, E.J., Challenor, P.G., Medina-Elizalde, M., and Lester, A.J., 2011, Sea-level probability for the last deglaciation-A statistical analysis of far-field records: Global and Planetary Change, v. 79, p. 193-203, doi:10.1016/j.gloplacha.2010.11.002.

Storlazzi, C.D., and Griggs, G.B., 2000, Influence of El Niño-Southern Oscillation (ENSO) events on the evolution of central California's shoreline: Geological Society of America Bulletin, v. 112, p. 236249.

Storlazzi, C.D., and Wingfield, D.K., 2005, Spatial and temporal variations in oceanographic and meteorologic forcing along the central California coast, 1980-2002: U.S. Geological Survey Scientific Investigations Report 2005-5085, 39 p., available at http://pubs.usgs.gov/sir/2005/5085/.

Tissot, B.N., Yoklavich, M.M., Love, M.S., York, K., and Amend, M., 2006, Benthic invertebrates that form habitat on deep banks off southern California, with special reference to deep sea coral: Fishery Bulletin, v. 104, p. 167-181.

Trembanis, A.C., and Hume, T.M., 2011, Sorted bedforms on the inner shelf off northeastern New Zealand-Spatiotemporal relationships and potential paleo-environmental implications: Geo-Marine Letters, v. 31, p. 203-214, doi:10.1007/s00367-010-0225-8.

U.S. Geological Survey, 2009, National Archive of Marine Seismic Surveys: U.S. Geological Survey database, available at http://walrus.wr.usgs.gov/NAMSS/.

U.S. Geological Survey and California Geological Survey, 2010, Quaternary fault and fold database of the United States: U.S. Geological Survey database, accessed April 5, 2014, at http://earthquake.usgs.gov/hazards/qfaults/. 
Waelbroeck, C., Labeyrie, L., Michel, E., Duplessy, J.C., McManus, J.F., Lambeck, K., Balbon, E., and Labracherie, M., 2002, Sea-level and deep water temperature changes derived from benthic foraminifera isotopic records: Quaternary Science Reviews, v. 21, p. 295-305.

Wagner, D.L., and Gutierrez, C.I., 2010, Preliminary geologic map of the Napa $30^{\prime} \times 60^{\prime}$ quadrangle, California: California Geological Survey, scale 1:100,000, available at http://www.conservation.ca.gov/cgs/rghm/rgm/Pages/preliminary_geologic_maps.aspx.

Weber, K.M., List, J.H., and Morgan, K.L., 2005, An operational Mean High Water datum for determination of shoreline position from topographic lidar data: U.S. Geological Survey Open-File Report 2005-1027, available at http://pubs.usgs.gov/of/2005/1027/.

Wentworth, C.K., 1922, A scale of grade and class terms for clastic sediments: Journal of Geology, v. 30, p. 377-392.

Witter, R.C., Knudsen, K.L., Sowers, J.M., Wentworth, C.M., Koehler, R.D., Randolph, C.E., Brooks, S.K., and Gans, K.D., 2006, Maps of Quaternary deposits and liquefaction susceptibility in the central San Francisco Bay region, California: U.S. Geological Survey Open-File Report 2006-1037, scale 1:24,000, available at http://pubs.usgs.gov/of/2006/1037/.

Wong, F.L., Phillips, E.L., Johnson, S.Y, and Sliter, R.W., 2012, Modeling of depth to base of Last Glacial Maximum and seafloor sediment thickness for the California State Waters Map Series, eastern Santa Barbara Channel, California: U.S. Geological Survey Open-File Report 2012-1161, 16 p., available at http://pubs.usgs.gov/of/2012/1161/.

Wright, D.J., Pendleton, M., Boulware, J., Walbridge, S., Gerlt, B., Eslinger, D., Sampson, D., and Huntley, E., 2012, ArcGIS Benthic Terrain Modeler (BTM), v. 3.0: Environmental Systems Research Institute and NOAA Coastal Services Center, Massachusetts Office of Coastal Zone Management, accessed February 1, 2013, at http://esriurl.com/5754.

Wright, J.D., 2000, Global climate change in marine stable isotope records, in Noller, J.S., Sowers, J.M., and Lettis, W.R., eds., Quaternary geochronology-Methods and applications: Washington, D.C., American Geophysical Union, p. 427-433, doi:10.1029/RF004p0427. 